UNIVERSIDADE DO VALE DO RIO DOS SINOS - UNISINOS UNIDADE ACADÊMICA DE PESQUISA E PÓS-GRADUAÇÃO PROGRAMA DE PÓS-GRADUAÇÃO EM DESIGN ESTRATÉGICO NÍVEL MESTRADO

DANIELA SPERB MORAES

NEGOCIAÇÕES NO PROCESSO DE DESIGN

Um estudo sobre a perspectiva do cliente na validação do projeto

Porto Alegre 
DANIELA SPERB MORAES

NEGOCIAÇÕES NO PROCESSO DE DESIGN:

Um estudo sobre a perspectiva do cliente na validação do projeto

Dissertação apresentada como requisito parcial para obtenção do título de Mestre pelo Programa de Pós-Graduação em Design Estratégico da Universidade do Vale do Rio dos Sinos - UNISINOS

Orientador: Prof. Dr. Guilherme Corrêa Meyer

\section{Porto Alegre}


M827nMoraes, Daniela Sperb

Negociações no processo de design : um estudo sobre a perspectiva do cliente na validação do projeto / por Daniela Sperb Moraes. -2016.

92 f. : il., $30 \mathrm{~cm}$.

Dissertação (mestrado) — Universidade do Vale do Rio dos Sinos, Programa de Pós-Graduação em Design, 2016.

Orientação: Prof. Dr.Guilherme Corrêa Meyer.

Catalogação na Fonte:

Bibliotecária Vanessa Borges Nunes - CRB 10/1556 
Daniela Sperb Moraes

NEGOCIAÇÕES NO PROCESSO DE DESIGN:

Um estudo sobre a perspectiva do cliente na validação do projeto

Dissertação apresentada como requisito parcial para obtenção do título de Mestre pelo Programa de Pós-Graduação em Design Estratégico da Universidade do Vale do Rio dos Sinos - UNISINOS.

Aprovado em

BANCA EXAMINADORA

Prof. Dr. Humberto Nicolás Sica Palermo - UFRGS

Prof. Dr. Celso Carnos Scaletsky - UNISINOS

Prof. Dr. Leandro Miletto Tonetto - UNISINOS

Prof. Dr. Guilherme Corrêa Meyer - UNISINOS 


\section{AGRADECIMENTOS}

Aproveito este valioso espaço para expressar minha profunda gratidão por algumas pessoas que foram essenciais à realização do mestrado e concretização deste trabalho:

meus colegas da turma do mestrado, pessoas tão especiais, que possibilitaram que o período do programa fosse muito mais proveitoso, prazeroso e menos cansativo;

os professores do programa de mestrado, que influenciaram, significativamente, no meu modo de pensar e de pesquisar, cada um com sua excepcional bagagem teórica e prática;

os participantes das entrevistas, que disponibilizaram seu tempo, contribuindo com informações fundamentais para a realização da pesquisa;

os professores, Dr. Celso Carnos Scaletsky e Dr. Leandro Miletto Tonetto, por suas contribuições na banca de qualificação;

o Prof. Dr. Guilherme Correa Meyer, que desempenhou o papel de orientador com excelência e dedicação, mostrou-me uma dimensão humana da pesquisa e não faltou com esforços para que eu seguisse adiante;

meus clientes, que me possibilitaram, através de cada projeto, vivenciar as "zonas indeterminadas da prática profissional", enquanto o mestrado abria os meus horizontes do aprendizado;

meu namorado, Matheus, que acompanhou de perto os altos e baixos da minha relação com a pesquisa, motivando-me tanto nos momentos de limitação quanto nos momentos de superação. Obrigada por seu apoio e carinho, que não faltaram; e

meus queridos pais, Cléo e Marilaine, que sempre incentivaram e apoiaram todas as formas de aprendizado que eu pudesse ter, desde os primeiros dias da minha existência. Seu apoio foi fundamental nessa trajetória! Sou imensamente grata a eles e às minhas irmãs queridas, Marcela e Fernanda -, família com a qual tenho o privilégio de conviver e me desenvolver como ser humano.

Além destas pessoas importantíssimas, não posso deixar de agradecer a Deus e ao Universo que permitiram que eu vivenciasse um período de imenso aprendizado e crescimento, colocando-me junto a pessoas tão especiais e auxiliando-me para que tudo ocorresse da melhor forma possível! Muita gratidão! 


\section{RESUMO}

O processo projetual pode ocorrer em meio a negociações, conversações, trocas de valores e conflitos entre cliente e designer. Nessas negociações, o designer busca compreender e atender as expectativas dos atores envolvidos na rede em que o projeto se desenvolve, objetivando a aceitação de suas proposições. Dentre tais atores, entende-se que o cliente desempenha um papel fundamental no processo projetual, pois sem a aprovação do cliente, o artefato é impedido de desempenhar seus papéis na sociedade. Identificada tal importância, o objetivo desse estudo é compreender a perspectiva do cliente sobre o processo de validação no design, no segmento moveleiro. $O$ termo validar, que tem o significado associado a "demonstrar a existência ou verdade de algo por evidências"1 (MERRIAMWEBSTER, 2014a, tradução nossa), é utilizado em diferentes contextos no campo do Design. No presente estudo, o emprego do termo parte da ideia de Krippendorff (2006), que explica que como o projeto não é um futuro observável, como ocorre em outras áreas, o designer precisa argumentar e convencer os atores envolvidos sobre o potencial de suas ideias para, então, fazer com que estes validem suas proposições. Para atingir o objetivo almejado no estudo, foi realizada uma pesquisa exploratória, na qual a coleta de dados ocorreu por meio de entrevistas em profundidade com clientes. Foram considerados "clientes", as pessoas responsáveis por fazerem a aprovação das proposições de design em empresas do setor moveleiro, localizadas na Serra Gaúcha e que, normalmente, contratam escritórios externos para o desenvolvimento de seus artefatos. Os resultados das entrevistas foram tratados por meio da Análise de Conteúdo e mostram alguns aspectos presentes no processo de validação: 1) grupos heterogêneos, compostos por participantes de diferentes áreas das organizações, são formados para as avaliações das novas proposições de design; 2) a validação não ocorre em um momento específico, mas ao longo de todo o processo projetual e em diferentes etapas; 3) alguns aspectos da relação entre o cliente e o designer, bem como os motivos pelos quais o designer é contratado podem influenciar consideravelmente na validação do projeto; 4) a validação de uma proposição independe da linearidade do processo projetual do designer; 5) o processo de validação ocorre por meio de

\footnotetext{
${ }^{1}$ Do original em inglês: "to show the existence or truth of by evidence".
} 
uma espécie de coalescência, ou seja, pela combinação de seus componentes. A pesquisa alcançou, portanto, uma aproximação dos motivos que fazem o cliente validar uma proposição, ampliando o tema da validação no design e contribuindo para os campos teórico e prático dessa disciplina.

Palavras-Chave: Validação no Design. Relação cliente $X$ designer. Design do Produto. Indústria Moveleira. Perspectiva do Cliente. 


\begin{abstract}
The design process can take place between negotiations, conversations, exchanges of values and conflicts between client and designer. In these negotiations, the designer seeks to understand and meet the expectations of the actors involved in the network where the project is developed, aiming the acceptance of his proposals. Among these actors, it is understood that the client plays a key role in the acceptance the design process, because without the client approval, the artifact is unable to perform their roles in society. Identified such importance, the aim of this study is to understand the client perspective on the validation process in design. The term validate, that has meaning associated with "demonstrate the existence or truth of something by evidence" (MERRIAM-WEBSTER, 2014a), is used in different contexts in the field of Design. In this study, the use of the term comes from the idea of Krippendorff (2006), who explains that as the project is not an observable future, as in other areas, the designer needs to argue and convince stakeholders about the potential of his ideas to make them validate their proposals. To achieve the intended objective in the study, an exploratory survey was conducted, in which the data was collected through in-depth interviews with clients. Were considered "clients", the people responsible for making the approval of the design proposals in the furniture sector companies, located in Serra Gaucha region, and that normally hire outside firms to develop their artifacts. The results of the interviews were processed through Content Analysis and show some aspects present in the validation process: 1) heterogeneous groups composed of participants from different areas of organizations are formed for evaluation of new design proposals; 2) the validation does not occur at a specific time, but along the entire design process at different stages; 3) some aspects of the relationship between the client and the designer, as well as the reasons why the designer is hired can influence considerably in the project validation; 4) validation of a proposition is independent of the linearity of the design process of the designer; 5) The validation process occurs through a kind of coalescence, or by the combination of its components. The survey reached therefore an approximation of the reasons that make the client validate a proposition, expanding the theme validation in design and contributing to the theoretical and practical fields of this discipline.
\end{abstract}


Key-words: Validation in Design. Relationship client $X$ designer. Product Design. Furniture Industry. Client Perspective. 


\section{LISTA DE FIGURAS}

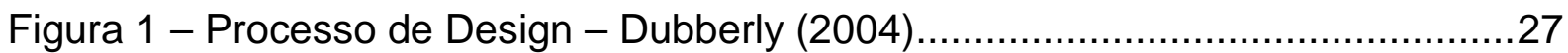

Figura 2 - Processo de Design - Koberg e Bagnall (1972) ……….....................29

Figura 3 - Oscilação entre a análise e síntese no processo de design - Dubberly

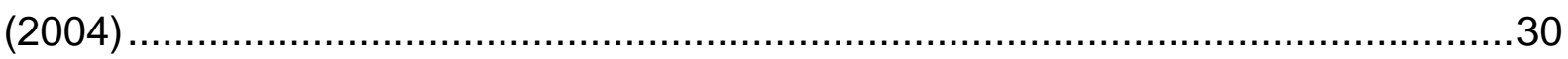

Figura 4 - Relação de categorias e subcategorias identificadas na pesquisa ...........46

Figura 5 - Informantes da pesquisa e nomenclatura utilizada nas referenciações ...47 


\section{LISTA DE TABELAS}

Tabela 1 - Subcategoria 1.1 Qualidade do Design de produtos desenvolvidos 49

Tabela 2 - Subcategoria 1.2 Adequação das proposições com as estratégias da empresa

Tabela 3 - Subcategoria 1.3 Adequação das proposições com a capacidade técnica/produtiva da empresa .51

Tabela 4 - Subcategoria 1.4 Qualidade do conceito ..........................................52

Tabela 5 - Subcategoria 1.5 Inovação na proposição …………………………...52

Tabela 6 - Subcategoria 1.6 Proposições que "encantam"/conquistam o cliente .....53

Tabela 7 - Subcategoria 2.1 Experiência da empresa com o designer ....................54

Tabela 8 - Subcategoria 2.2 Contrato entre a empresa e o designer .54

Tabela 9 - Subcategoria 2.3 Conhecimento específico do designer sobre o tipo/área de projeto .55

Tabela 10 - Subcategoria 2.4 Admiração/ confiança no trabalho do designer 56

Tabela 11 - Subcategoria 3.1 Presença de grupos heterogêneos para a avaliação das proposições

Tabela 12 - Subcategoria 3.2 Validação ocorre ao longo de todo o processo de desenvolvimento e em diferentes etapas

Tabela 13 - Subcategoria 3.3 Validação independe da linearidade do processo projetual .59

Tabela 14 - Subcategoria 3.4.1 Briefing e Pesquisa 60

Tabela 15 - Subcategoria 3.4.2 Apresentação 61

Tabela 16 - Subcategoria 4.1 Parceiros e concorrentes 62

Tabela 17 - Subcategoria 4.2 Proximidade geográfica do designer com a empresa63 Tabela 18 - Subcategoria 4.3 Identificação/sintonia da empresa com o designer e seu portfólio. .63

Tabela 19 - Subcategoria 4.4 Especificidade do projeto X conhecimento do designer 64

Tabela 20 - Subcategoria 4.5 Amizade/proximidade de proprietários da empresa ..65 Tabela 21 - Subcategoria 4.6 Nome em ascensão ou reconhecido no mercado 


\section{SUMÁRIO}

1 INTRODUÇÃO

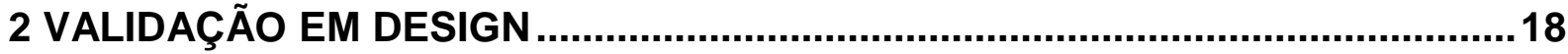

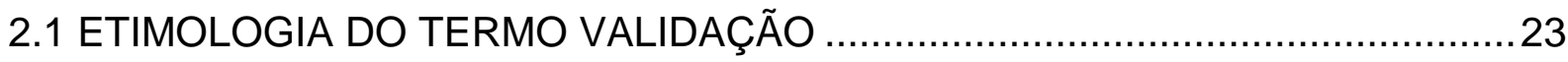

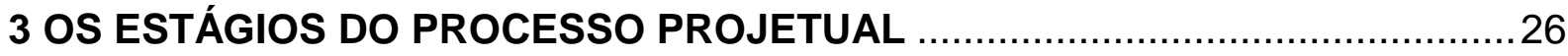

4 O PROCESSO PROJETUAL E AS DINÂMICAS SOCIAIS ..................................33

4.1 A RELAÇÃO ENTRE CLIENTE E DESIGNER .............................................. 33

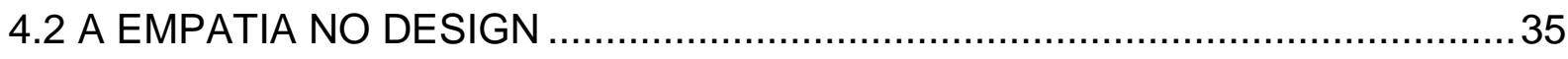

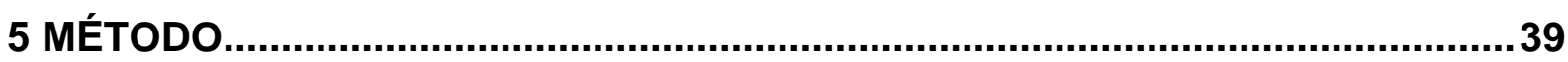

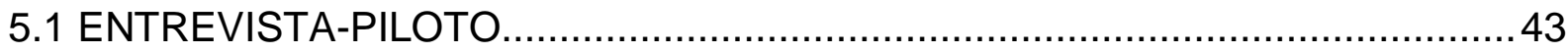

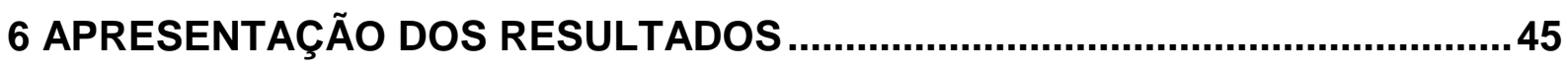

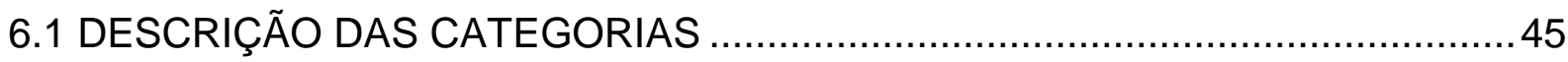

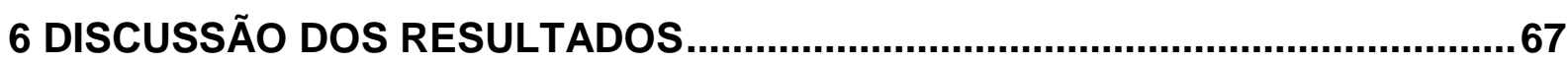

6.1 PRESENÇA DE GRUPOS HETEROGÊNEOS PARA AVALIAÇÃO DAS

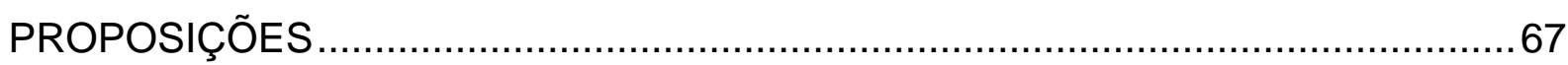

6.2 A VALIDAÇÃO OCORRE AO LONGO DO PROCESSO DE DESENVOLVIMENTO E EM DIFERENTES ETAPAS …….................................70

6.3 A RELAÇÃO DO CLIENTE COM O DESIGNER E OS ASPECTOS SOCIAIS DA

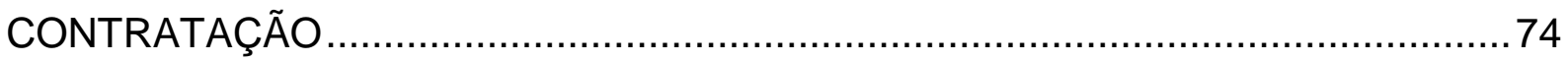

6.4 A VALIDAÇÃO INDEPENDE DA LINEARIDADE DO PROCESSO PROJETUAL77 6.5 O PROCESSO DE VALIDAÇÃO OCORRE POR MEIO DA COALESCÊNCIA DE

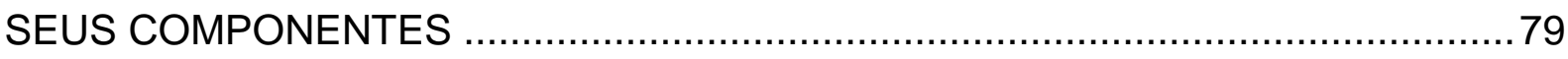

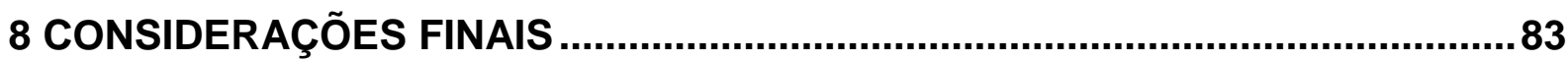

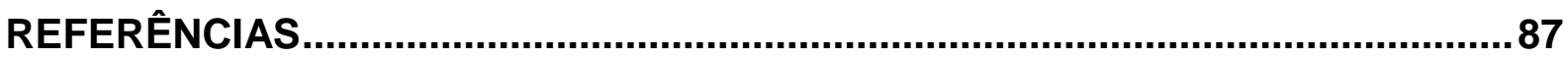

APÊNDICE A - GUIA PARA PESQUISA DE CAMPO …................................... 


\section{INTRODUÇÃO}

"Nosso trabalho é dar ao cliente, a tempo e custo esperados, não o que ele quer, mas o que ele nunca sonhou que queria; e quando ele consegue isto, ele reconhece-o como algo que ele quis o tempo todo". (DENYS LASDUN, apud CROSS, 2011, p. 3, tradução nossa)2. A frase parece traduzir a habilidade que os designers têm em atender os desejos implícitos dos clientes - aquilo que eles mesmos não sabem e tampouco expressam. Mas, ao mesmo tempo em que essa habilidade confere mérito ao profissional, também se constitui em um enorme desafio.

No mercado atual, ainda é difícil se pensar na atividade de Design sem que a figura do cliente, aquele que contrata os serviços do Designer, seja considerada. No decorrer de um projeto, independente da sua especificidade, o contato entre o cliente e designer pode se tornar constante e próximo, já que a maioria das definições projetuais e até mesmo o nascimento do produto ou serviço costumam depender da aprovação do cliente.

O processo projetual quase sempre é acompanhado de conversações entre cliente e designer, cujo principal objetivo é chegar a um resultado que atenda às expectativas de ambas as partes. (MC DONNELL, 2009). Além disso, tanto o cliente quanto o designer costumam trazer e transferir seus valores pessoais e profissionais para essas conversações. Le Dantec acredita que "alguns valores do cliente irão corresponder com aqueles do designer, enquanto alguns valores serão estranhos para o designer."3 (LE DANTEC, 2009, p. 4, tradução nossa).

Quando os valores ou interesses de ambos são conflitantes, negociações entre esses atores costumam ocorrer, onde cada um luta por seus próprios interesses. Essas negociações, segundo Meyer (2010), nem sempre ocorrem em harmonia, pois os interesses em jogo podem ser muito divergentes, assim como as próprias posições ocupadas por esses atores. Em um projeto desenvolvido numa organização, os gestores, por exemplo, podem estar mais preocupados com as oportunidades de mercado, investimento e retorno do mesmo, enquanto o designer

\footnotetext{
2 Do original em inglês: "Our job is to give the client, on time and on cost, not what he wants, but what he never dreamed he wanted; and when he gets it, He recognises it as something he wanted all the time".

${ }^{3}$ Do original em inglês: "Some of the client's values will correspond with those of the designer, while some values will be foreign to the designer".
} 
pode ater-se muito mais às especificações técnicas e à estética do novo produto. (BAXTER, 2011).

Independente de quais são os interesses de cada uma das partes envolvidas, o designer deve agir como um mediador, interpretando esses anseios, compreendendo esses atores para, então, chegar a um resultado que atenda a todos. Nesse contexto, sabe-se da importância da empatia, já que o designer projeta, na maior parte das vezes, para o outro. De uma forma geral, pode-se dizer que empatia consiste na profunda compreensão do outro, na experiência de ver o mundo através dos seus olhos e sentir o mundo através de suas emoções. (JORDAN, 1986; DEN OUDEN, 2012).

Em meio às negociações entre os atores envolvidos, o designer também busca meios de validar suas proposições junto ao cliente, isto é, fazer com que suas ideias sejam aceitas. A presente pesquisa, portanto, tem como objetivo: compreender a perspectiva do cliente sobre o processo de validação no Design, no segmento moveleiro. Busca-se, dessa forma, enxergar através das lentes do cliente para entender o que é mais relevante para ele durante a aprovação de uma proposição de design.

Sob o tema que norteia a pesquisa, apresentam-se alguns objetivos específicos, que deverão contribuir para o alcance do objetivo geral, bem como auxiliar na compreensão do problema de pesquisa. São eles:

a) identificar as principais evidências aos quais os clientes se atêm na validação de uma proposição de design no segmento moveleiro;

b) relacionar os aspectos presentes no processo de validação aos estágios de projeto;

c) avaliar de que forma a validação de uma proposição em design está relacionada com aspectos do perfil do profissional contratado (ex: experiência, reconhecimento no mercado, premiações recebidas, entre outros).

O termo validação, da forma como é utilizado no presente estudo, parte da abordagem de Krippendorff (2006), que argumenta que, ao projetar um produto, o designer deve convencer os atores envolvidos que o projeto irá funcionar de acordo com certas evidências associadas ao que o produto promete. O autor (2006, p. 260) acredita que, na prática projetual, os designers precisam validar suas propostas de formas muito diferentes das que os cientistas o fazem, pois, enquanto estes 
explicam o mundo observável, através de evidências construídas no passado, os designers projetam aquilo que ainda não é "um futuro observável". Por isso, eles buscam demonstrar às pessoas, de alguma maneira, que suas ideias têm suficiente valor para serem concretizadas, ou seja, para se tornarem, efetivamente, esse "futuro observável".

Para compreender melhor a ideia da validação no design, uma revisão bibliográfica será apresentada, demonstrando como o termo tem sido utilizado em diferentes contextos dentro do próprio campo. De forma geral, uma das maneiras em que a palavra é utilizada diz respeito à avaliação de teorias, métodos e modelos, enquanto a outra trata da certificação, aprovação de propriedades e desempenho de artefatos.

Uma pesquisa etimológica demonstrou que o significado do termo validação está relacionado com legitimação, corroboração, confirmação, reconhecimento e, portanto, com a comprovação da veracidade de algo. (MERRIAM-WEBSTER, 2014b, tradução nossa). Validar significa "demonstrar a existência ou verdade de algo por evidências"4. (MERRIAM-WEBSTER, 2014c, tradução nossa). Fica implícito, nessa definição, a necessidade de uma confirmação, de um reconhecimento, que no processo de design, ocorre através do aceite da proposição pelo cliente.

Neste processo de validação, que ocorre, normalmente, durante o desenvolvimento do projeto, envolvem-se, dentre outros atores, principalmente o cliente e o designer (ou uma equipe de designers). Algumas pesquisas foram realizadas sobre a relação entre cliente e designer no processo projetual, nas quais são abordadas, por exemplo, as trocas de valores e negociações que costumam ocorrer durante esse período. (LE DANTEC, 2009 e 2010; MC DONNELL, 2009). Poucos estudos, entretanto, se ocuparam em compreender a ótica do cliente neste processo de interação sobre o projeto. Para um designer, a perspectiva do cliente é essencial e, geralmente, ocupa papel de destaque entre os demais atores, já que afeta diretamente o processo de tomada de decisões sobre os rumos de um projeto.

É o cliente quem normalmente escolhe o designer a ser contratado, investe seus recursos nesse profissional e, ainda, é quem normalmente faz a aprovação da proposição de design. Sendo assim, pode-se dizer que sem a corroboração do

\footnotetext{
${ }^{4}$ Do original em inglês: "to show the existence or truth of by evidence".
} 
cliente no processo de design, o produto, ou o que quer que o designer tenha projetado, poderá não existir e tampouco desempenhar seus papéis sociais.

Dentre os possíveis problemas que geralmente ocorrem no processo de negociação do projeto entre cliente e designer, pode-se mencionar o conflito de expectativas entre ambas as partes. Isto pode acontecer, por exemplo, nos casos em que o resultado esperado de uma proposição de design pode não ser explicitado pelo cliente e nem questionado pelo profissional. $O$ designer, ao analisar as informações sobre o projeto, interpreta o problema à sua maneira de ver o mundo, com base em suas experiências e crenças. Essa leitura, traduzida através de uma proposição, em geral, é distinta daquela que o cliente faz e, portanto, daquilo que este espera em termos projetuais.

Outra possível barreira nesse processo, é que o designer pode concentrar seus esforços em algo durante o projeto - como uma etapa metodológica, por exemplo, que considera decisiva para a validação de sua proposta de design -, enquanto, na verdade, para o cliente, o fator que motiva a sua aprovação pode ser outro, muito diferente daquele suposto pelo designer.

Além dos problemas acima, também podem ser citadas as frequentes alterações de projeto solicitadas pelo cliente, durante o processo. Estas modificações constantes, geralmente indesejadas pela maioria dos profissionais, também acarretam um tempo muito maior para desenvolvimento dos produtos, refletindo-se, também, em custos. A dificuldade e demora em validar uma proposição, podem evidenciar a falta de compreensão que os designers têm da perspectiva do cliente. Essa falta de compreensão ocorre, em geral, com os problemas indefinidos ou nos chamados "brienfings abertos.

As divergências exemplificadas, inerentes à atividade de projeto, demonstram, conforme explica Schön (2000), que a prática profissional não é um campo objetivo e regular. Ela apresenta zonas indeterminadas, problemas malestruturados, incerteza e conflitos de valores, tais quais os descritos anteriormente. Assim, o uso de metodologias mais reflexivas e menos instrumentais se faz cada vez mais necessário. Perspectivas centradas em outros atores, além do designer, como o design centrado no usuário ou o design participativo, também ganham espaços cada vez maiores na prática projetual (MAO et al., 2005; SANDERS; STAPPERS, 2008). 
Em relação ao método da pesquisa, foi realizado um estudo exploratório, por objetivarmos compreender melhor o processo de validação, cuja realidade é pouco conhecida na área do design. Assim, a principal técnica de coleta de dados utilizada foi a entrevista em profundidade, realizada com os atores que esta pesquisa busca melhor compreender: os clientes. Após as transcrições, as informações decorrentes das entrevistas foram submetidas ao método de análise de conteúdo. Segundo Moraes (1999, p. 2),

Essa análise, conduzindo a descrições sistemáticas, qualitativas ou quantitativas, ajuda a reinterpretar as mensagens e a atingir uma compreensão de seus significados num nível que vai além de uma leitura comum.

Quanto ao perfil do cliente considerado na pesquisa, optou-se por selecionar um segmento industrial específico. O foco do estudo são empresas da Serra Gaúcha, do setor moveleiro, que contratam serviços de design para o desenvolvimento de seus produtos, os quais produzem e comercializam. Este setor é considerado de grande importância para a atividade de design no Brasil, segundo Bürdek (2010), apresentando elevados índices de exportação.

O trabalho se apresenta em três capítulos de fundamentação teórica, um capítulo dedicado ao detalhamento do método utilizado, um capítulo com a apresentação dos resultados e outro com a sua discussão, além das considerações finais. O primeiro capítulo, intitulado "Validação em design", faz uma revisão bibliográfica sobre a utilização do termo validação no campo do design, uma breve discussão sobre a etimologia do termo e explica, ainda, como este será tratado na pesquisa. O segundo capítulo, chamado de "Os estágios do processo projetual", trata da metodologia de projeto, explicitando os principais estágios abordados pela literatura, pelos quais o projeto é submetido. O terceiro capítulo, cujo título é "O processo projetual e as dinâmicas sociais", discorre sobre a relação entre o cliente e o designer, através de alguns estudos já realizados, enfatizando o papel do cliente nesse contexto. $O$ capítulo destaca, também, a importância da empatia no processo projetual, por meio de uma revisão teórica.

Acredita-se que compreender a percepção do cliente sobre o processo de validação em design pode trazer importantes considerações para o designer e seu processo projetual. Ao procurar entender a ótica do cliente, o designer pode ter mais 
amplo alcance do contexto de projeto. Por isso, a presente pesquisa poderá estimular o designer a refletir sobre o quanto seus esforços, durante as etapas e atividades de projeto, apresentam características valorizadas pelo cliente e, portanto, relevantes para a validação da proposição.

Pretende-se não apenas contribuir para a atividade profissional, mas, devido à incipiência no que diz respeito aos estudos sobre o tema, a contribuição deverá ser de ordem teórica também. Krippendorff (2006), por exemplo, categoriza alguns tipos de validação, mas não explicita quais são as evidências, especificamente, pelas quais o designer normalmente valida sua proposição junto aos atores envolvidos. Além disso, o próprio tema da validação no design apresenta poucos estudos, além de Krippendorff (2006, p. 260), que o tratam no sentido de "aprovar proposições projetuais" de uma forma mais ampla. Conforme veremos no primeiro capítulo, na literatura em Design, normalmente a validação é abordada em contextos diferentes do que aqui se pretende. Por fim, a ideia de apresentarmos a perspectiva do cliente, também é relevante para a teoria e prática do campo do Design, já que este costuma ser um tema pouco enfatizado. 


\section{VALIDAÇÃO EM DESIGN}

$\mathrm{Na}$ pesquisa desenvolvida, o tema da validação no design parte da abordagem de Klaus Krippendorff (2006). O autor acredita que como os designers dependem de outros para aprovarem e realizarem suas proposições - o que se explica pelo princípio da empatia (que será descrito no próximo capítulo) -, suas ideias precisam ser narradas, visualizadas e comunicadas junto àqueles que podem trazer os artefatos à vida. Nessa tarefa, eles recorrem a sensibilidades artísticas ou ainda, a alguns instrumentos facilitadores desse processo. (KRIPPENDORFF, 2006).

O autor menciona cinco maneiras que podem ser utilizadas pelo designer para atestar suas ideias na prática:

a) validade demonstrativa: serve para provar o valor ou o funcionamento de um artefato; pode representar apenas o aspecto sensorial daquilo que se quer demonstrar, através de desenhos, simulações computacionais, etc.;

b) validade experimental: serve para comprovar, através de evidências, se os propósitos, expectativas e hábitos dos usuários ou clientes serão atendidos. Pode ser um protótipo, por exemplo, que permita a sua interação com os sujeitos;

c) validade interpretativa: serve para suportar ideias, através de discursos vindos de outras áreas, que devem ser interpretados e rearticulados para o campo do design;

d) validade metodológica: consiste no crítico exame dos métodos utilizados para a proposição e servem para justificá-la e argumentar a sua validade;

e) validade pragmática: consiste nas proposições vistas como "autoevidentes", pois não requerem maiores argumentos para validação. Esta está nas mãos dos atores envolvidos no processo, além do designer.

Através de uma revisão bibliográfica, percebeu-se que o termo validação no design tem sido utilizado de formas diferentes da qual Krippendorff (2006) utiliza. Nos estudos que abordam o tema, identificou-se o emprego da palavra, na maioria das vezes, de duas formas distintas: a primeira é no sentido de avaliar teorias, métodos e modelos, enquanto a segunda é no sentido de certificar, aprovar propriedades técnicas e desempenho de artefatos.

Não é interesse dessa pesquisa avançar nas discussões sobre esse primeiro tipo de validação, contudo um breve sumário será apresentado a seguir, objetivando 
esclarecer que o termo, nos seguintes casos, não está relacionado à avaliação de proposições projetuais ou artefatos, mas sim, aos métodos e pesquisa no Design.

Pedersen et al (2000) exploram a questão da validação no primeiro contexto mencionado, ou seja, na pesquisa e nos métodos de design. Eles observam que, nas áreas de pesquisa, que dependem de pressupostos subjetivos, a validação ancorada na tradição do método científico - que demanda uma verificação formal, rigorosa e quantitativa -, se torna problemática. Os autores, então, investigam os problemas que esse tipo de abordagem pode trazer para validar um método de design, recorrendo às raízes da epistemologia, conforme será brevemente discutido.

Para entender o problema da validação na pesquisa, segundo Pedersen et al (2000), é necessário partir da visão dos racionalistas e empiristas. Para eles, as verdades são absolutas e inatas - o que se relaciona com a lógica do fundamentalismo. Este, por sua vez, serviu de base para o positivismo lógico, movimento que dominou o campo científico até 1960 e cuja ideia central é o princípio da verificação. Nesse princípio, os conhecimentos só podiam ser atestados se julgados por meio de experiências. Os conhecimentos, portanto, que não podem ser formalizados por investigação analítica ou empírica não têm sentido. A maioria dos positivistas considera as ideias trazidas de disciplinas como metafísica, religião e estética, como inferiores àquelas produzidas pela ciência.

Sendo este tipo de pensamento problemático, para a validação de pressupostos subjetivos, como os do design, Pedersen et al (2000) acreditam que outras escolas epistemológicas devem ser estudadas. Kant (1933, apud PEDERSEN et al., 2000), por exemplo, acreditava que o conhecimento parte da experiência e que nem todas as verdades são absolutas e inatas, podendo algumas serem agregadas pela mente humana. Hegel (1959, apud PEDERSEN et al., 2000), por outro lado, entendia que os conflitos e contradições eram elementos necessários da verdade e que esta é mais um processo do que um estado fixo das coisas. Ele enfatizava que o conhecimento é dependente da história, cultura e sociedade e, por isso, não há base neutra para o conhecimento e nem verificação inteiramente objetiva.

Quine (1953, apud PEDERSEN et al., 2000) argumenta que escolhemos uma determinada forma de fazer as coisas, porque é conveniente, porque causa pouca perturbação à teoria existente e não devido a algum princípio científico absoluto. Este pressuposto desafia a noção que apenas o conhecimento racional é válido. A 
definição de conhecimento intuitivo, por sua vez, parte da ideia de que nossa capacidade de ser racional depende de uma habilidade de exercitar julgamentos inteligentes que não podem ser completamente capturados em sistemas de regras. Baseados nisso, Pedersen et al. (2000) acreditam que o conhecimento científico é ancorado na racionalidade por fatos e na intuição para valores.

Assim, Pedersen et al. (2000) questionam a própria validação formal, rigorosa e quantitativa, tendo em vista que a impossibilidade de avaliações totalmente racionais desafia a existência da objetividade. Eles acreditam que um tipo de validação contextual, conversacional e subjetiva é mais lógica. Deste modo, a validação relativista, na qual esta é vista como um processo de construção de confiança com relação aos propósitos dos novos conhecimentos é mais apropriada para problemas abertos, como os do design.

Green (2011), ao contrário de Pedersen et al. (2000), acredita numa abordagem padronizada para a validação de métodos de Design e menciona como os métodos emergentes, tais como o chamado "índice de risco de confiabilidade relativa (r3i)"5 devem ser testados e validados. O autor descreve, por exemplo, como um experimento foi desenvolvido para consolidar a validação de uma metodologia, através de um estudo de caso. Ele procura demonstrar, também, como o pensamento corrente sobre validação na pesquisa em design poderia ser aplicado na prática e como os resultados da abordagem sugerida - a validação experimental, sugerem uma abordagem padronizada para a validação de métodos de design.

Tratando ainda do emprego do termo "validação", relacionado a teorias, métodos e modelos, Love (2000) aborda a teoria na pesquisa em Design, explorando seus atuais problemas e sugerindo um novo método metateórico. É esse novo método, que segundo o autor, ajuda a estabelecer coerência e compatibilidade entre os conceitos de teorias diferentes, valida teoria e conceito, e, ainda, descobre aspectos "ocultos" da teoria de design. O autor (2000, p. 310, tradução nossa) acredita que com o uso da análise metateórica, a "Confusão, proliferação semântica e falta de coerência na Teoria do Design podem ser reduzidas". ${ }^{6}$

5 Índice de risco de confiabilidade (r3i) é uma metodologia que visa apoiar - com relação à confiabilidade - o conceito da seleção desenhos. (GREEN, 2011).

${ }^{6}$ Do original em inglês: "Confusion, semantic proliferation and lack of coherency in design theory may be reduced by the application of meta-theoretical analysis". 
De forma resumida, na revisão teórica acima Petersen et al. (2000) questionam o problema da validação tradicional em relação aos métodos de design, enquanto Green (2011) propõe a validação desses métodos, através de experimentos. Love (2000), por sua vez, propõe um método, que, dentre outros propósitos, busca validar teorias e conceitos na pesquisa em Design. Os primeiros autores, portanto, tratam da validação de métodos de Design, enquanto o último, ao contrário, trata de um método para a validação de aspectos teóricos da área.

No segundo contexto, no qual o termo validação é usado no sentido de aprovar propriedades técnicas e desempenho de artefatos, os autores estão interessados em um tipo de certificação voltada ao projeto desenvolvido pelos designers. É este o contexto que mais se aproxima como a proposta da presente pesquisa. Nesse tipo de validação, testes, experimentos, instrumentos e métodos podem ser utilizados para averiguação e visualização de determinadas características do que está sendo projetado.

Conforme comentado no início desse capítulo, Krippendorff (2006, p. 263-4) classifica algumas formas de validação normalmente utilizadas no Design, como a visualização de croquis e desenhos, por exemplo, chamada de "validade demonstrativa" ou a manipulação de protótipos, classificada pelo autor como "validade experimental". Nesse sentido, Krippendorff destaca que o Design e a Ciência compartilham a crença de que a validação de suas proposições pode ser suportada por um crítico exame dos métodos utilizados. Entende-se, com isso, que ao analisar os métodos utilizados para a projetação de um artefato, por exemplo, pode-se compreender alguns motivos de sua configuração atual. O endendimento e esclarecimento desses aspectos, portanto, são capazes de auxiliar a validação de um projeto.

Lan, Arteau e Sirard (2004) apresentam um método para validação e posterior certificação de sistemas de segurança, utilizados por trabalhadores a grandes alturas, com vários componentes feitos a mão e que, normalmente, não são regulamentados. Através da distinção entre os testes de força dinâmica e de desempenho, identificam-se os ensaios apropriados que devem ser executadas na certificação de tais componentes ou montagem dos mesmos.

Exner et al. (2014), por outro lado, analisam o uso da prototipagem para validação de sistemas produto-serviço, que devido à sua complexidade, carecem de métodos apropriados para testes. Os protótipos são meios de validação da 
funcionalidade e desempenho dos produtos e serviços e distinguem-se, de uma forma geral, em físicos e virtuais. Integrando as características desses diferentes tipos de protótipos, os autores (2014) aplicam a abordagem da Prototipagem Híbrida Inteligente em um estudo de caso, para validar um sistema produto-serviço: um sistema de compartilhamento de triciclos. Aqui, novamente o interesse é pela validação do Design desenvolvido.

Nos casos acima, o termo validação é empregado relacionando-se diretamente à proposição projetual, no sentido de avaliação, julgamento de determinadas características físicas e desempenho - tanto de artefatos quanto de sistemas produto-serviço -, desenvolvidos por designers. Os casos citados diferemse, entre outros aspectos, porque os autores do primeiro estudo (LAN; ARTEAU; SIRARD, 2004) tratam de produtos já existentes, enquanto os do segundo, (EXNER et al., 2014), tratam de um sistema produto-serviço em desenvolvimento. Entende-se que este tipo de avaliação ocorre constantemente durante o processo projetual, tanto por parte do projetista, quanto por parte dos demais atores envolvidos, como clientes, fornecedores e usuários. Exner et al. (2014, p. 69, tradução nossa) enfatizam:

\begin{abstract}
A validação nos processos de desenvolvimento é um fator chave para um processo projetual bem sucedido. Isto pode ser habilitado com diferentes métodos ou ferramentas para permitir o teste de diferentes parâmetros de design, como requisitos técnicos ou usabilidade. ${ }^{7}$
\end{abstract}

Consideradas as perspectivas através das quais se vem tratando o tema no Design, o segundo tipo de emprego do termo, citado nos parágrafos anteriores, é o mais próximo da forma como este será abordado na pesquisa. Salienta-se que neste trabalho, a validação é entendida como o processo onde a proposição de Design, bem como todas as suas características, passa pela avaliação e aprovação por parte dos atores envolvidos na atividade projetual. Krippendorff (2006) argumenta que no design tais atores empregam diferentes perspectivas e compreensões acerca de uma mesma proposição. O entendimento do usuário, por exemplo, é diferente do entendimento do designer ou até mesmo do cliente contratante. $O$ autor acredita que

\footnotetext{
7 Do original em ingles: "The validation in development processes is a key factor to a successful design process. It can be enabled with different methods or tools to allow a testing of different design parameters, e.g. technical requirements or usability".
} 
cada um deles tem razões para ver de forma diferente aquilo que eles mesmos consideram ser o mesmo artefato.

\subsection{ETIMOLOGIA DO TERMO VALIDAÇÃO}

Ao buscar o significado da palavra validar, encontra-se: "a) suportar ou corroborar numa base sólida ou de autoridade; b) reconhecer, estabelecer ou ilustrar o merecimento ou legitimidade de...”. E a palavra validação, por sua vez, está relacionada com legitimação, corroboração, confirmação, reconhecimento, e, portanto, com a comprovação da veracidade de algo. (MERRIAM-WEBSTER, 2014a, 2014b, tradução nossa).

Acredita-se que para estabelecer o merecimento ou legitimidade de uma proposta projetual, os atores eleitos para esta tarefa estabelecem determinados critérios, conscientes ou não, onde a aceitação de tal proposição passa a se apoiar e se justificar. Assim, eles aprovam as proposições, baseados, por exemplo, na visualização de croquis e desenhos, que, segundo Krippendorff (2006, p. 263-4), trata-se da "validade demonstrativa" ou na manipulação de protótipos, que corresponde à "validade experimental".

Conforme citado acima, o primeiro significado da palavra "validar" refere-se ao embasamento, do que se está avaliando, em base sólida ou de autoridade. É importante salientar que essa autoridade parece não existir, em sua forma convencional, dentro do campo do design, ao contrário do que ocorre na maior parte dos campos profissionais. Conforme explica Schön (1983, p. 292,), na "relação tradicional" entre profissional e cliente, o cliente costuma acatar a autoridade do profissional contratado, por ele ser especialista em sua área de atuação. No design, entretanto, Meyer (2010, p. 73) acredita que ocorre uma espécie de inversão dessa regra. Como, em geral, o cliente não aceita a autoridade do profisisonal, muitas vezes é ele quem assume a posição de autoridade. Assim, a validação no Design tende a ocorrer por agentes externos ao campo, que, na maior parte das vezes, trata-se do cliente.

Exner et al. (2014, p. 69, tradução nossa) diferenciam os termos verificação e validação no design. Eles descrevem a verificação como "A correlação entre as

\footnotetext{
${ }^{8}$ Do original em inglês: "a) to support or corroborate on a sound or authoritative basis; b) to
} recognize, establish, or illustrate the worthiness or legitimacy of". 
especificações que o processo toma como entrada (ou "input") e o produto como o resultado (ou "output") do processo"9, enquanto validação significa "Testar se o produto é adequado para o propósito ao qual foi desenvolvido ou não"10. Apesar de esclarecedora, essa visão sobre o termo validação é insuficiente para explicar o tema nesta pesquisa, pois, conforme Krippendorff (2006) comenta, as ideias do designer ainda não são um futuro observável e, por isso, são difíceis de serem simplesmente testadas. Entende-se que a ideia de teste poderia ser melhor aplicada a protótipos ou artefatos já produzidos.

O conceito trazido por Exner et al. (2014) não abarca os aspectos subjetivos da validação no Design, como os valores simbólicos e estéticos, que normalmente envolvem um artefato. Nesse sentido, o questionamento que Pedersen et al. (2000) fazem com relação à validação formal e rigorosa é pertinente. E, conforme sugerem, uma validação contextual, conversacional e subjetiva seria mais apropriada no campo do Design.

Se considerada essa natureza subjetiva e não puramente racional da validação no Design, os termos "avaliação" e "julgamento" também podem ser examinados. Goldschmidt (1992), por exemplo, aborda o tema da avaliação arquitetônica - com o que ela se ocupa e o que ela deixa de lado. Nesse estudo, Collins (1971, p. 68, apud GOLDSCHMIDT, 1992) vê o julgamento como um processo racional e evolutivo, incorporado em contextos profissionais. Os critérios que ele elaborou são artísticos, científicos e algo que ele se refere como "expertise profissional". Goldschmidt (1992) também discorre sobre os padrões de pensamento do designer, que resultarão nas suas respectivas avaliações e tomadas de decisão sobre o processo projetual. Ressalta-se que, nesse caso, os critérios de julgamento tratados são centrados no designer, em sua própria avaliação durante a atividade de projeto e na avaliação da proposição desenvolvida. Mas, mesmo que essa avaliação do próprio designer seja relevante para a evolução do projeto, este ainda passa pelo julgamento e posterior validação dos agentes externos ao campo.

Através da revisão bibliográfica, é possível perceber que a literatura em Design apresenta uma lacuna acerca da validação das proposições projetuais. Conforme os estudos demonstraram, para o processo de validação, a instância

\footnotetext{
${ }^{9}$ Do original em inglês: "the correlation between the specifications that the process gets as input, and the product as the output of the process".

${ }^{10}$ Do original em inglês: "testing whether the product is suitable for the purpose it is developed for or not".
} 
técnica é relevante, como a avaliação e verificação de determinadas características físicas e de desempenho de artefatos. Contudo, sabe-se que outros aspectos também compõem este processo. Até que ponto, por exemplo, a apresentação do projeto ao cliente ou o perfil do profissional contratado são relevantes para a aprovação de uma proposição de design? Nos capítulos seguintes, serão apresentados alguns estudos sobre outros aspectos em que se acredita envolverem o processo, como estágios projetuais e dinâmicas sociais. 


\section{OS ESTÁGIOS DO PROCESSO PROJETUAL}

Partindo-se do princípio que a validação das proposições do designer ocorre durante os estágios projetuais, procurar-se-á, neste capítulo, apresentar um panorama sobre o processo de design. Os próximos parágrafos tratam de esclarecer, através de uma breve revisão bibliográfica, quais são as principais etapas que, geralmente, pautam um processo de projeto.

Os estágios projetuais são etapas que podem ser encontradas em um processo de design. Inicialmente, a teoria estabelecia a necessidade de um processo linear e com etapas sequenciais. Segundo Bazjanac (1974, p. 5, apud PASCHOALIN, 2012, p. 44), "Teóricos do design procuraram descrever seus processos por meio de modelos sistemáticos, invariavelmente como uma sequência de atividades bem definidas". Esses modelos sistemáticos surgiram com a necessidade do "Estabelecimento de uma base crítica do projetar que permitisse o seu esclarecimento, em detrimento dos valores subjetivos ou intuitivos comumente associados à atividade." (PASCHOALIN, 2012, p. 31). O surgimento de tais modelos também era uma maneira de esclarecer o que o designer fazia e de que forma 0 fazia.

O processo projetual, no contexto dos métodos de design surgidos no anos 1960 e 1970, segundo Paschoalin (2012, p. 50), podia ser descrito como "Uma sequência sistemática de atividades bem definidas, relacionadas à superação de dificuldades/resolução de problemas". Essa sequência de atividades servia de apoio ou orientação ao designer, durante o processo de resolução de problemas: guiava-o para os caminhos no qual deveria percorrer na busca da solução de projeto. Nesse período, surgiu um dos paradigmas da metodologia de design, introduzido por Simon - com a racionalização do processo de solução de problemas, onde o design era visto como um processo de busca racional, instrumental. Entendia-se que o problema de design era o que definia o espaço do problema a ser explorado na busca de uma potencial solução. (DORST, 2003).

A lógica de processo projetual mais amplamente utilizada atualmente é ainda decorrente desse paradigma, que, segundo Findelli (2001), é materialista, agnóstico e utiliza métodos positivistas. Segundo o autor, o processo ocorre da seguinte forma: 
1 - Uma necessidade ou problema é identificado: situação $A$;

2 - Uma meta final ou solução é imaginada e descrita: situação $B$;

3 - A ação de designer é o link causal pelo qual a situação $A$ é transformada na situação B. (FINDELLI, 2001, p. 9, tradução nossa). ${ }^{11}$

Segundo o autor (2001), esse também é um dos pensamentos mais difundindos no ensino de Design, que fundamenta-se na crença de que se o problema está estabelecido, a solução será proposta com mais facilidade.

Dubberly (2004), que coletou inúmeras descrições de processos de design de diversos autores, explica que, de forma geral, conforme mostra a figura 1, o processo costuma ter uma "entrada" (input) e uma "saída" (output) e que entre estes ocorre uma transformação, ou o processo em si. Pode-se entender que a entrada seria, por exemplo, o problema projetual, trazido pelo cliente ao designer e que a saída seria o projeto finalizado, ou ainda, o artefato chegando ao mercado. A transformação seria o conjunto de atividades realizadas pelo designer para a resolução do problema de projeto.

Figura 1 - Processo de Design - Dubberly (2004)

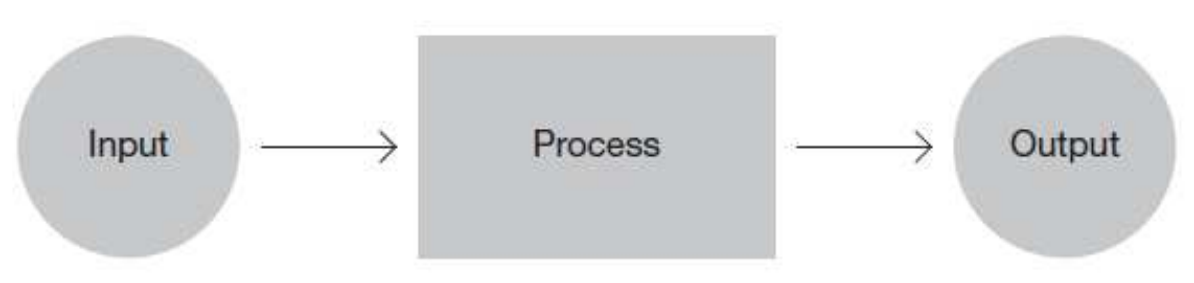

Fonte: Dubberly (2004, p. 14).

Ao analisar diferentes abordagens do processo de resolução de problemas, Koberg e Bagnall (1972, apud DUBBERLY, 2004), acreditam que os estágios básicos de análise e síntese costumam ser um denominador comum entre tais

\footnotetext{
${ }^{11}$ Do original em inglês: "1) A need, or problem, is identified: situation A; 2) A final goal, or solution, is imagined and described: situation $B$; and 3) The act of design is the causal link by which situation $A$ is transformed into situation B".
} 
abordagens. Isso significa que, de modo geral, primeiro, quebra-se o problema em partes para exame (análise) e depois se remonta a situação, baseado em nosso entendimento de melhorias, descobertas através de estudos (síntese). Designers frequentemente descrevem seu próprio processo envolvendo: inicialmente, a criação de muitas opções, onde ocorre a divergência; e posteriormente, o estreitamento dessas opções, onde acontece a convergência. (DUBBERLY, 2004).

Na prática projetual, pode-se dizer que a análise corresponde aos momentos em que o designer realiza o levantamento dos dados necessários ao projeto, desenvolvendo, nessa fase, as pesquisas - sobre o contexto do projeto ou para obter insights criativos -, o entendimento do briefing e coleta de demais informações que subsidiarão as suas atividades. A síntese, por outro lado, seria o momento em que as informações coletadas são reunidas durante o processo criativo, na busca de uma solução para o problema de design. Nessa fase, a proposição começa a tomar forma - seja através de um esboço rápido ou de uma representação técnica mais elaborada -, incorporando os dados obtidos na fase de análise e aqueles do próprio universo do designer.

Alguns autores começam a incluir o estágio de avaliação nas metodologias sobre o processo projetual, como Asimow (1962, apud PASCHOALIN, 2012), que foi um dos pioneiros a estabelecer a atividade projetual como um processo sequenciado, onde duas escalas operacionais estão presentes. Uma destas escalas, que para o autor é chamada de estrutura de resolução de problemas, é composta pelos estágios de análise, síntese e avaliação.

Jones (1970/1992, apud PASCHOALIN, 2012), assim como Asimow (1962, apud PASCHOALIN, 2012) também inclui a avaliação, como etapa posterior a síntese e essencial a este processo:

Uma das observações mais simples e comum sobre o projetar, é uma sobre a qual muitos autores concordam, é que ela inclui os três estágios essenciais de análise, síntese e avaliação. Estes podem ser descritos em termos simples como "quebrar os problemas em pedaços", "juntar as peças de um novo modo" e "testar para descobrir as consequências de colocar o novo arranjo em prática" [...] Os três estágios aqui são referidos como divergência, transformação e convergência. (JONES, 1970/1992, p. 63, apud PASCHOALIN, 2012, p. 46). 
Koberg e Bagnall (1972, apud DUBBERLY, 2004, p. 16), conforme mostra a Figura 2, ampliam o processo, que, anteriormente, dividiram em apenas duas fases, para sete fases distintas. Os autores incluem aceitação e a fase de definição (que por outros autores também é chamada de transformação), mantêm a fase de análise e transformam a fase de síntese em conceituação, seleção e implementação e agregam, assim como Jones (1970/1992, apud PASCHOALIN, 2012), a fase de avaliação no final do processo.

Figura 2 - Processo de Design - Koberg e Bagnall (1972)

$\begin{array}{cccc}\text { análise definição síntese } & \\ \text { analisar definir conceituar selecionar implementar } \\ \text { aceitar analisar definir conceituar selecionar implementar avaliar }\end{array}$

Fonte: Koberg e Bagnall (apud DUBBERLY, 2004, p. 33). Adaptação e tradução livre da autora.

Entende-se que na fase descrita como avaliação, que compõe os processos descritos, tanto o designer quanto o cliente podem visualizar e avaliar os resultados da análise. Testes e pesquisas com usuários podem ser realizadas nesse estágio. A avaliação também está vinculada à apresentação do projeto ao cliente.

A partir de uma perspectiva de engenharia, Cross (2000, apud DUBBERLY, 2004) desenvolveu um modelo descritivo do processo de design, baseado nas atividades principais que o designer desempenha. O modelo inicia com a exploração inicial do espaço do problema e segue com a geração de um conceito pelo designer. Após, a proposta é submetida à avaliação frente aos objetivos, restrições e critérios estabelecidos no briefing projetual. A fase final consiste na comunicação do projeto, onde este está pronto para produção.

As descrições citadas abordam metodologias projetuais que, em geral, apresentam uma ordem sequencial de atividades durante a atividade de design, sendo, portanto, consideradas metodologias lineares. Por outro lado, Dubberly 
(2004) entende que podemos ver o processo de design como uma oscilação da atenção do designer entre a análise e a síntese. $O$ designer vai e volta para as mesmas etapas, quantas vezes forem necessárias, conforme mostra a Figura 3.

Figura 3 - Oscilação entre a análise e síntese no processo de design - Dubberly (2004)

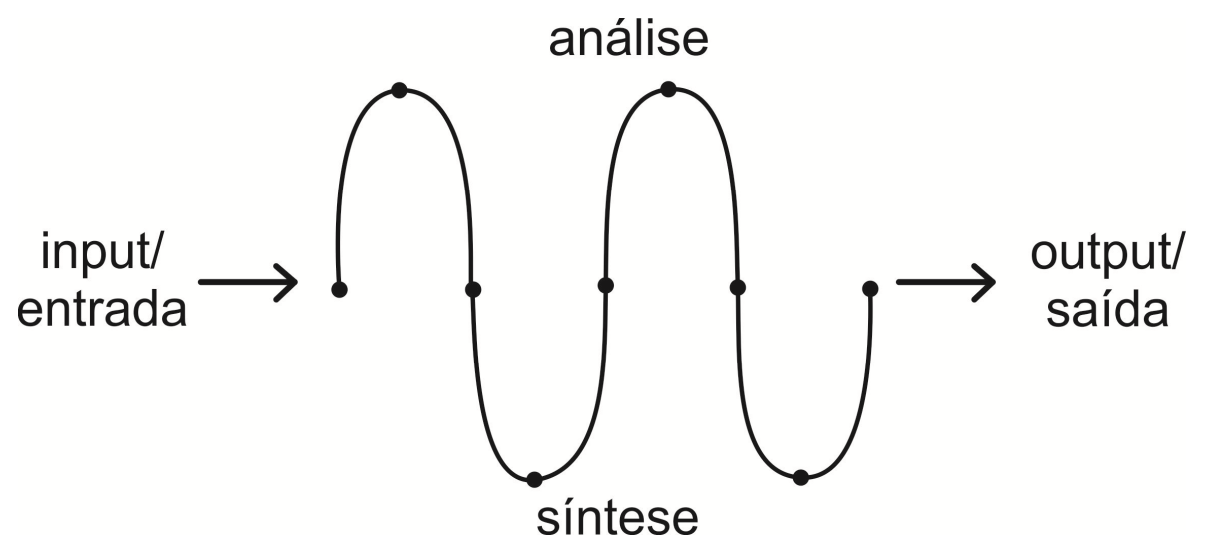

Fonte: Dubberly (2004, p. 20). Adaptação e tradução livre da autora.

Dorst (2003) acredita que o projeto nem sempre é acompanhando de problemas determinados, onde as informações costumam vir prontas para o designer. Os problemas da prática também podem ser subdeterminados - quando apresentam algum tipo de lacuna a ser preenchida, e, indeterminados - quando as informações são imprecisas. Dessa forma, para a resolução desses tipos de problema, os métodos convencionais não são suficientes. O autor acredita, portanto, na co-evolução dos problemas com as soluções de design. Ele explica que o design criativo é um processo de refinamento da formulação de um problema, juntamente $e$ em paralelo, com o desenvolvimento de ideias para a solução, com constantes análises, sínteses e avaliações por parte do designer.

A exploração do problema de design, ao mesmo tempo em que se busca uma solução para este, também se assemelha à visão de Schön (2000, p. 43), que vê o ato de projetar como um processo que envolve complexidade e síntese. "Os designers juntam coisas e fazem com que outras coisas venham a existir, lidando, no processo, com muitas variáveis e limites, algumas conhecidas desde o início e outras descobertas durante o processo de projeto". As consequências e implicações 
descobertas levam "À reconstrução da coerência inicial - uma conversação reflexiva com os materiais de uma situação." Nesse tipo de conversação, existe um diálogo com o que se está projetando e o próprio projeto, que, conforme se desenvolve, fornece respostas para o designer.

Findeli (2001), também sugere uma lógica diferente daquela que se pensava com a racionalização do processo de solução de problemas. $O$ autor acredita que 0 novo ensino em Design - para se adequar às exigências do profissional da nossa era -, deveria levar em conta essa nova lógica para a resolução de problemas. Aqui, o designer e o projeto não estão dissociados, como acontecia nos métodos mais tradicionais, surgidos nos anos 1960 e 1970 e descritos anteriormente:

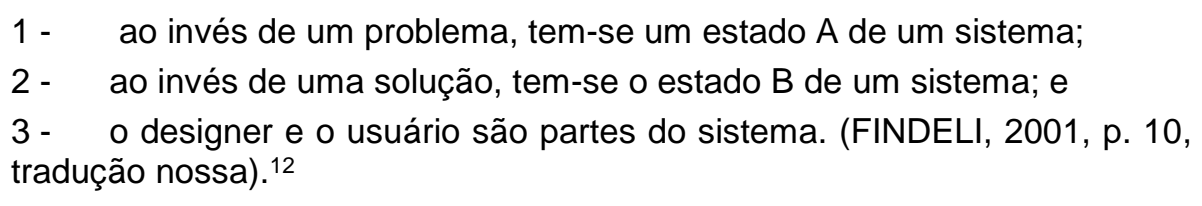

Neste contexto, a tarefa do designer é entender a dinâmica do sistema, agindo dentro dele, e não sobre ele. Segundo Findeli (2001), o profissional e o usuário, ao se envolverem neste processo, também são transformados por ele.

Procurou-se, através dessa breve revisão teórica, explicitar algumas metodologias projetuais, bem como os principais estágios do processo de design. Mesmo que as abordagens sobre o processo projetual tenham sofrido uma considerável transformação, desde os anos 1960 até os dias de hoje, ainda assim, é possível identificar os estágios que equivalem à análise, à síntese e à avaliação embora tais estágios estejam frequentemente entrelaçados uns com os outros.

Apesar da literatura ter abordado, ao longo dos anos, o processo projetual e os métodos de design existentes, não se sabe, dentre eles, o que é mais eficiente na aprovação de tais projetos, ou melhor, não se sabe o que compõe exatamente o processo de validação. Acredita-se que apenas comprovações técnicas, através de desenhos e protótipos, não sejam suficientes para o cliente. Em que medida, por exemplo, o portfólio e a experiência do profissional não afetam de alguma forma o processo de validação do que este projeta? Também não se conhece outros fatores, além dos métodos, que compreendem o processo de validação, como as dinâmicas

12 Do original em inglês: "1) Instead of a problem, we have: state A of a system; 2) Instead of a solution, we have: state $B$ of the system; and 3) The designer and the user are part of the system (stakeholders)". 
sociais envolvidas. Dessa forma, pretende-se abordar aspectos das dinâmicas sociais, onde o projeto se desdobra, no próximo capítulo. 


\section{O PROCESSO PROJETUAL E AS DINÂMICAS SOCIAIS}

\subsection{A RELAÇÃO ENTRE CLIENTE E DESIGNER}

Alguns estudos, que serão exemplificados a seguir, demonstram que 0 processo projetual ocorre em meio a conversações e negociações entre cliente e designer - ora colaborativas, ora conflitantes.

Mc Donnell (2009), ao analisar as conversações sobre o projeto de um prédio, entre os arquitetos e os usuários-clientes, observou que a evolução do projeto é negociada colaborativamente, de forma que cada um contribui com informações do seu próprio território de atuação e experiências. Os encontros entre os participantes, conforme observado pelo autor, giraram em torno da busca por um consenso acerca das necessidades do projeto. Esse entendimento compartilhado é criado e revelado, conforme a negociação do projeto avança.

Em geral, no decorrer de um processo projetual, tanto o cliente quanto o designer costumam trazer e transferir seus valores pessoais e profissionais para as conversações. Esses valores são expostos e negociados para buscar soluções potenciais. Le Dantec (2009), que analisou as mesmas conversações do estudo de Mc Donnell, acredita que "Alguns valores do cliente irão corresponder com aqueles do designer, enquanto alguns valores serão estranhos para o designer"13 (LE DANTEC, 2009, p. 4, tradução nossa). Entre os valores do designer, expostos durante as conversações, estão: a experiência profissional, o conhecimento sobre o campo do design, além dos valores pessoais que formam sua personalidade. Já o cliente, além desses valores pessoais, traz às conversações as noções de como o artefato seria usado e como se encaixaria na vida das pessoas ou nas suas próprias vidas (no caso dele ser o usuário, também). Estes valores, de uma forma geral, servem de base para como o designer e o cliente acessam o projeto.

Meyer (2010) observou o cotidiano de um escritório de Design pelo período de seis meses, através de um estudo etnográfico. Ele analisou diferentes aspectos de um processo projetual de um triciclo e acompanhou os pormenores da relação entre os designers do escritório e o cliente contratante. O autor menciona que nessa negociação entre os envolvidos, existem interesses em jogo, e que tanto o cliente,

\footnotetext{
${ }^{13}$ Do original em inglês: "Some of the client's values will correspond with those of the designer,
} while some values will be foreign to the designer." 
quanto o designer lutam por eles "No momento em que definem seus papéis". Meyer explica que nem sempre esse processo ocorre em harmonia:

\begin{abstract}
O que complica a negociação é que estes interesses nem sempre são equivalentes, sendo algumas vezes conflitantes: em alguns momentos 0 que o cliente quer não vai ao encontro com o que o designer entende ser o melhor para o mercado; em outros, o que o usuário aponta é contrário ao que o cliente contratante está disposto a aceitar. (MEYER, 2010, p. 75).
\end{abstract}

No processo projetual, acompanhado por Meyer (2010) em sua pesquisa, observa-se que a avaliação do cliente era sempre muito valorizada pela equipe de designers. O cliente em questão apontava elementos que lhes eram agradáveis, outros que desgostava, outros dos quais "ele não abria mão". O cliente tinha, ainda, o poder de "congelar" o projeto, pois sem o seu aval, os designers não conseguiam dar andamento ou finalizar o processo. Isto denota certa predominância do cliente nas decisões projetuais - o que faz com que, muitas vezes, o projeto tome um rumo diferente do que o designer pretendia. De uma forma geral, entende-se que a opinião do cliente deve ser considerada desde o princípio da projetação.

Cross (2011) procura desvendar aspectos da habilidade do Design e apresentou alguns estudos de campo realizados, como o de Larry Bucciarelli, que atuou como observador- participante em projetos de design industrial. Através desse estudo, Bucciarelli concluiu, assim como Meyer (2010), que o design não é apenas um processo pessoal e cognitivo, mas "Um processo social de interação e negociação entre diferentes participantes onde cada um busca defender seu próprio mundo objeto ${ }^{14 "}{ }^{15}$ (CROSS, 2011, p. 20, tradução nossa).

O processo de design, como mostra o estudo de Bucciarelli (CROSS, 2011) e como também atesta Mc Donnell (2009), consiste em obter consenso entre as partes- cujos interesses são diferentes - através de negociações, visando à construção de significado. Nessas negociações até mesmo a ambiguidade é importante, pois, ao conferir diferentes sentidos a uma mesma palavra ou objeto, permite que ocorra uma troca de conhecimento entre os participantes e faz com que cada um modifique o seu "mundo objeto", acarretando na reformulação de significados. Dessa forma, após uma reunião para apresentação e discussão de

\footnotetext{
14 "mundo-objeto": o conhecimento específico dos atores participantes sobre os aspectos do objeto a ser projetado. (CROSS, 2011).

${ }^{15}$ Do original em inglês: "a social process of interaction and negotiation between the participants who each bring to bear their own object world".
} 
uma proposição de Design, por exemplo, os participantes agregam novas informações ao projeto e também saem com uma nova bagagem de conhecimentos.

Tais conversações são, de alguma forma, permeadas por empatia, onde os participantes precisam compreender uns aos outros. A compreensão sobre o termo e os estudos desenvolvidos serão explicitados a seguir.

\subsection{A EMPATIA NO DESIGN}

A atividade desempenhada pelo designer se embaralha por entre uma rede, na qual agentes materiais e humanos se relacionam (MEYER, 2010). Os agentes materiais são representados, por exemplo, pelos contratos, políticas, prazos e pelo próprio projeto, enquanto os agentes humanos podem ser considerados os clientes, fornecedores, usuários e o próprio designer, todos desempenhando determinado papel e importância no processo projetual. Dependendo do escopo de cada projeto, o papel desses atores pode variar e assumir proporções menores ou maiores.

Em meio a essa rede, é esperado que o designer assuma um papel de articulador, mediador entre os atores envolvidos, conforme explica Deserti (2007, p. 61): "O designer deve então confrontar-se com um sistema complexo de exigências e de vínculos, frequentemente contraditórios entre si, respeito aos quais ele deve operar como mediador." O autor destaca a importância, nesse sistema ou rede, da empresa e do consumidor - cujas exigências precisam ser interpretadas individualmente -, e menciona também o cenário competitivo que envolve 0 designer.

No papel de mediador, o designer precisa utilizar-se de certa competência na compreensão e empatia para com os atores envolvidos. Como ele projeta, fundamentalmente, para outros, e não para si, a empatia tende a estar presente em todos os projetos de Design. Diversos autores - tanto da área da gestão quanto do Design -, abordam e destacam a importância da empatia no projeto. (KELLEY; KELLEY, 2013; MATTELMÄKI; VAAJAKALLIO; KOSKINEN, 2014; DEN OUDEN, 2012; VISSER et al., 2005).

Empatia, segundo Jordan (1986, p. 2), é "A experiência afetivo-cognitiva de entendimento da outra pessoa". O reconhecimento de sua importância ganha espaço no final dos anos 1990, com a necessidade de explorar os sentimentos, humores e sua relação com as soluções de Design, através do Design Empático. 
Essa abordagem interpretativa foca nas experiências cotidianas, nos desejos, humores e emoções das atividades humanas, transformando-os em inspirações projetuais. (MATTELMÄKI; VAAJAKALLIO; KOSKINEN, 2014).

Para auxiliar na pesquisa de campo da abordagem empática, Den Ouden (2012) acredita que todas as anotações, vídeos e fotografias são válidos se traduzidos em insights projetuais para produtos ou serviços que visem melhorar a vida das pessoas. Técnicas mais desenvolvidas também têm surgido para obtenção de empatia com o usuário, como o mapeamento contextual (VISSER et al., 2005), onde designers e pesquisadores utilizam métodos generativos de mapeamento do contexto de interação das pessoas com os produtos. Segundo Visser et al. (2005), o contexto abarca todos os fatores que influenciam a experiência do uso de um produto. Os autores acreditam que o estudo deste contexto, proporciona o ganho de empatia com usuários. Além disso, com tais técnicas, os designers evitam julgamentos antecipados sobre o produto ou usuário, possibilitando, assim, a criação de conceitos mais inovadores.

Den Ouden (2012, p. 111, tradução nossa) explica que empatia requer um nível emocional de entendimento do público-alvo almejado, pois consiste em: "Um hábito mental de esforçar-se para ver o mundo através dos olhos dos outros, entender o mundo através de suas experiências e sentir o mundo através de suas emoções". ${ }^{16}$ Quanto mais o designer sentir e conhecer a realidade do público para quem projeta, há mais probabilidade que o artefato satisfaça as necessidades e desejos - nem sempre expressos, desse público.

Kelley e Kelley (2013) complementam que o fato de compreender o que as pessoas fazem, da forma como fazem, pode gerar insights significativos para imaginar o que elas fariam no futuro. Os autores, integrantes da IDEO ${ }^{17}$, mencionam que, em todo programa de inovação, um dos três fatores que deve estar presente e em equilíbrio com os demais é o fator humano, que diz respeito ao profundo entendimento das necessidades humanas. Para eles, empatia profunda com as pessoas torna as observações grandes fontes de inspiração. Kelley e Kelley (2013) acreditam que uma abordagem empática faz com que se mantenha presente a ideia de que se projeta para pessoas reais.

\footnotetext{
${ }^{16}$ Do original em inglês: "a mental habit of making the effort to see the world through the eyes of others, understand the world through their experiences and feel the world through their emotions".

17 IDEO: Empresa global de design que auxilia outras organizações a inovarem e crescerem, através do uso de abordagens como o "design thinking". (KELLEY; KELLEY, 2013).
} 
Quanto às fases e propósitos em que as pesquisas de caráter empático podem ser usadas, pode-se destacar: o início de um projeto, para obter inspiração; durante o desenvolvimento do projeto, para validar conceitos ou até mesmo para estimular a criatividade em momentos em que ela está escassa. (KELLEY; KELLEY, 2013).

O designer pode se valer da empatia em relação a qualquer um dos atores da rede de projeto, ou ainda, em relação a todos eles. A literatura em Design, contudo, aborda a questão da empatia, voltando-se predominantemente para o entendimento do usuário. Significativos esforços têm se concentrado na investigação do "design centrado no usuário", por exemplo, cujo processo de desenvolvimento parte de uma profunda compreensão das necessidades do usuário. (VERGANTI, 2008).

A abordagem do design centrado no usuário, considerada multidisciplinar e que abarca a questão da empatia, foi utilizada inicialmente nos Estados Unidos, na década de 70. A partir de então, cada vez mais os usuários têm influenciado e participado ativamente do processo projetual - principalmente nas fases iniciais, como ideação e conceituação. Acredita-se que o entendimento dos usuários é crucial para as questões de utilidade e usabilidade dos produtos. (MAO et al., 2005; SANDERS; STAPPERS, 2008).

Apesar da importância do usuário para o projeto, neste estudo procura-se envolver com o problema da empatia com relação ao cliente, objetivando compreender a sua perspectiva durante o processo de validação. Enfatiza-se a importância de interpretar os desejos e aspirações deste ator, que é uma peça chave da rede em que o projeto se desdobra. Para tornar mais clara a diferença entre o usuário e o cliente, convém estabelecer que, no contexto desta pesquisa, considera-se cliente quem contrata o designer ou o escritório, pagando pelo projeto, enquanto usuário é quem usufrui do que foi projetado - um produto, ou uma embalagem, por exemplo.

Enquanto Den Ouden (2012) enfatiza o papel relevante dos usuários, que acredita que se eles não adotarem o produto ou serviço para uso, a proposição não atingirá seus objetivos, Deserti (2007, p. 61), por outro lado, destaca a importância da empresa enquanto cliente a ser satisfeito:

a validade das soluções projetuais propostas por um designer não pode ser avaliada em termos absolutos, mas deve ser relacionada com a empresa, que deve efetivamente implementá-las, e com o mercado competitivo para o 
qual são destinadas. [...] Se o usuário final constitui a referência tradicional do designer no seu esforço de conjugar os aspectos formais com aqueles funcionais e de uso do produto, a empresa constitui o primeiro cliente a satisfazer.

Deserti (2007) também argumenta que, quando o design age como "entidade autônoma", ou seja, os escritórios ou consultorias externas à empresa, a interpretação das necessidades da organização se torna ainda mais relevante, pois ela se constitui em um cliente a ser satisfeito. Diferente de quando as equipes de design são internas e seus membros são funcionários da empresa, os escritórios externos não conhecem a fundo a realidade de seu cliente e, portanto, necessitam empregar mais tempo em algumas tarefas, como nas pesquisas contextuais, por exemplo. Da mesma forma, nesses casos, a validação de uma proposição também é importante, pois ela determina a satisfação da empresa-cliente com o escritório de design e sua possível contratação para projetos futuros.

Acredita-se que o processo de validação no Design ocorra em meio a essas conversações e negociações, conforme citado neste capítulo. Reitera-se, portanto, que a validação, não ocorra apenas por comprovações ou embasamentos técnicos, mas existe uma dinâmica social, onde 0 papel e a ação dos atores são determinantes para que a proposição seja validada. É necessário essa ampla performance dos projetos, no campo técnico do que propõem, e no âmbito social, influenciado pelo modo como os atores relacionam-se. Nesse contexto em que ocorre a validação, a perspectiva do cliente é fundamental, mas pouco abordada nos estudos de design. $O$ presente estudo, portanto, também visa preencher esta lacuna. 


\section{MÉTODO}

Ao almejar a compreensão do processo de validação, uma realidade pouco conhecida na área do design, os estudos que se realizam são exploratórios. Trata-se de uma investigação, na qual não se sabe exatamente o que se encontrará no caminho e, por isso mesmo, deve-se abster-se de julgamentos para "percorrê-lo". (MARTINS; THEÓPHILO, 2007). Similarmente, explica Gil (2009, p. 43):

Pesquisas exploratórias são desenvolvidas com o objetivo de proporcionar
visão geral, de tipo aproximativo, acerca de determinado fato. Este tipo de
pesquisa é realizado especialmente quando o tema escolhido é pouco
explorado e torna-se difícil sobre ele formular hipóteses precisas e
operacionalizáveis.

Pela dificuldade em formular hipóteses nas pesquisas exploratórias, conforme argumenta Gil (2009), o presente estudo não parte de premissas ou pressupostos já estabelecidos sobre o tema. Ao contrário, a técnica de coleta de dados escolhida nesta pesquisa, que será descrita posteriormente, permite uma "exploração" mais livre do universo a ser pesquisado.

Acredita-se que tanto as opiniões e percepções, quanto as evidências a que o cliente se atém no processo de validação em design podem ser das mais variadas naturezas. Para acessar um universo maior de possíveis resultados, procurou-se analisar a ótica de diferentes clientes em um mesmo segmento. Como se sabe que são vários os setores do mercado em que o designer pode atuar, um segmento em particular foi escolhido para realização desta pesquisa. Isto porque cada área possui suas características próprias e peculiaridades - as quais podem influenciar no processo de validação.

Dessa forma, o foco do estudo são empresas da Serra Gaúcha do setor moveleiro que contratam serviços de design para o desenvolvimento de seus artefatos e que os produzem e comercializam. Essas organizações são tratadas aqui como clientes. O setor moveleiro foi escolhido para o estudo, pois se qualifica como um dos pontos fortes das atividades de design no Brasil, com altos índices de exportação. Este segmento, além de apresentar tradição no design nacional, também teve elevados índices de crescimento nos últimos anos, apresentando um ritmo de crescimento da demanda maior que o da produção. (BÜRDEK, 2010; SEBRAE, 2014). 
Acerca da delimitação geográfica do presente estudo - a Serra Gaúcha, pode-se dizer que se deu por dois motivos: a facilidade operacional e o fato de situarem-se, no Rio Grande do Sul, os maiores polos produtores de móveis, como a cidade de Bento Gonçalves, com o maior percentual de concentração de empresas produtoras e exportadoras do Brasil. (SEBRAE, 2014). Na região sul, também acontecem importantes feiras deste segmento, como a Fimma Brasil, a Casa Brasil e a Movelsul, que buscam valorizar e fortalecer o setor moveleiro. (ASSOCIAÇÃO DAS INDÚSTRIAS DE MÓVEIS DO ESTADO DO RIO GRANDE DO SUL (MOVERGS), 2014).

Independentemente do porte, as empresas do setor moveleiro foram selecionadas em função de seu reconhecimento no âmbito do design. Em geral, as organizações que se destacam nesse sentido investem em design, seja consolidando um setor interno de desenvolvimento, seja contratando profissionais capacitados para lhes prestar serviços de projeto ou consultoria. Para que se atendam aos objetivos desta pesquisa, as organizações escolhidas precisam ter a cultura de contratar, ou já ter contratado, profissionais ou escritórios de Design externos à empresa - o que estabelece a "relação entre cliente e designer", almejada nesta pesquisa.

Os principais informantes da pesquisa são os agentes envolvidos com a validação de novas proposições de design nas organizações escolhidas; são os sujeitos que se ocupam das avaliações e decisões daquilo que os designers apresentam nessas organizações.

A técnica de coleta de dados escolhida para o estudo é a entrevista em profundidade com os informantes mencionados acima. Duarte (2004, p. 215) esclarece a utilidade dessa técnica de coleta:

Entrevistas são fundamentais quando se precisa/deseja mapear práticas, crenças, valores e sistemas classificatórios de universos sociais específicos, mais ou menos bem delimitados, em que os conflitos e contradições não estejam claramente explicitados. Nesse caso, se forem bem realizadas, elas permitirão ao pesquisador fazer uma espécie de mergulho em profundidade, coletando indícios dos modos como cada um daqueles sujeitos percebe e significa sua realidade e levantando informações consistentes que the permitam descrever e compreender a lógica que preside as relações que se estabelecem no interior daquele grupo, o que, em geral, é mais difícil obter com outros instrumentos de coleta de dados. 
Buscou-se contatar com pelo menos oito possíveis informantes, de diferentes empresas, para as entrevistas. Esses possíveis informantes eram as pessoas envolvidas com as decisões sobre as novas proposições de design em suas organizações. As organizações atendiam os requisitos mencionados acima, ou seja: pertencem ao setor moveleiro, estão alocadas na serra gaúcha e, por fim, costumam contratar ou já contrataram designers externos para o desenvolvimento de seus artefatos. Das oito pessoas contatadas, cinco delas aceitaram participar da pesquisa.

Foi utilizada a seguinte estratégia para a localização e convite dos informantes: primeiramente foram selecionadas as empresas que se enquadravam nos requisitos da pesquisa. Em um segundo momento, a pesquisadora investigou, através de contatos telefônicos e indicação de pessoas conhecidas, quem eram os responsáveis pela contratação e aprovação de novos projetos de artefatos nas empresas. Após a identificação desses sujeitos, foram feitos contatos telefônicos e virtuais diretamente com essas pessoas, convidando-as a participar da pesquisa. Essas últimas etapas foram as que mais desprenderam esforço, já que, normalmente, as organizações não expõem certas informações a desconhecidos. Finalmente, após o aceite dos possíveis informantes, foram agendados os dias e horários mais convenientes para a realização das entrevistas.

As entrevistas foram semiestruturadas, conforme roteiro detalhado no Apêndice $A$, a fim de que os interlocutores tivessem liberdade de abordar e explorar questões não previstas, mas pertinentes à compreensão dos fatos. (BAUER; GASKELL, 2002). Parte-se do pressuposto que ao se tratar de clientes, designers e projetos diferentes, as experiências resultantes desses processos também são completamente diferentes e, por isso, há necessidade de uma técnica mais livre de coleta de dados. Acredita-se que a não padronização de perguntas aos entrevistados é importante, pois, segundo Bauer e Gaskell (2002, p. 73), "As perguntas são quase que um convite ao entrevistado para falar longamente, com suas próprias palavras e com tempo para refletir". E, na pesquisa exploratória, "O entrevistado possui o papel central no palco e a sua fala é o principal insumo da pesquisa".

Com as autorizações dos informantes, as entrevistas tiveram gravação de áudio e foram todas realizadas nos próprios edifícios das organizações e escritórios, onde os informantes costumam desempenhar suas atividades profissionais. 
Entende-se que, por estarem familiarizados com esse ambiente, os entrevistados debateriam as questões com maior naturalidade. Com o intuito de acessar informações mais recentes, mais "frescas" na memória dos entrevistados, e, assim, favorecer uma maior explanação de ideias, procurou-se tratar dos últimos projetos de design contratados pela empresa (cliente) e desenvolvidos pelos designers.

Após as transcrições, as informações decorrentes das entrevistas foram submetidas ao método de Análise de Conteúdo. Segundo Moraes (1999, p. 2),

\footnotetext{
Essa análise, conduzindo a descrições sistemáticas, qualitativas ou quantitativas, ajuda a reinterpretar as mensagens e a atingir uma compreensão de seus significados num nível que vai além de uma leitura comum.
}

A Análise de Conteúdo, realizada nas informações transcritas da pesquisa de campo, baseia-se na proposta de Moraes (1999), que descreve um método composto por cinco etapas: preparação das informações; unitarização ou transformação do conteúdo em unidades; categorização ou classificação das unidades em categorias; descrição e interpretação. Uma breve descrição das etapas da análise será apresentada a seguir.

De um modo geral, a preparação das informações consiste, segundo Moraes (1999, p. 5), em "Identificar as diferentes amostras de informações a serem analisadas". Em seguida, é realizada a unitarização, definindo-se os elementos unitários de conteúdo - como palavras, frases, temas - a serem posteriormente classificados. A escolha destes elementos, como explica o autor (1999, p. 6), depende "Da natureza do problema, dos objetivos da pesquisa e do tipo de materiais a serem analisados".

Após a codificação das unidades de análise, pode-se partir para a categorização das informações. Na categorização, busca-se agrupar dados a partir da parte comum existente entre eles. "As categorias representam o resultado de um esforço de síntese de uma comunicação, destacando neste processo seus aspectos mais importantes". (MORAES, 1999, p. 7). O estabelecimento de categorias deve seguir um conjunto de critérios. Segundo Moraes (1999, p. 7), as categorias devem ser "válidas, exaustivas, homogêneas." A classificação dos elementos de conteúdo também deve ser mutuamente exclusiva e a mesma deve ser consistente.

$\mathrm{Na}$ quarta etapa, a etapa da descrição, o material resultante da classificação anterior deve ser comunicado. Um texto síntese para cada uma das categorias deve 
ser elaborado, o qual expresse o significado trazido pelas unidades de análise. (MORAES, 1999).

A quinta e última etapa consiste na interpretação dos dados, ou seja, é uma "Compreensão mais aprofundada do conteúdo das mensagens". (MORAES, 1999, p. 10). Esta interpretação, segundo o autor, pode tanto relacionar-se aos estudos da fundamentação teórica já realizados pelo pesquisador anteriormente, como também relacionar-se a estudos a serem desenvolvidos pelo pesquisador, a partir das informações geradas pela análise, posteriormente. Neste último caso, "A própria construção da teoria é uma interpretação". (MORAES, 1999, p. 10). A interpretação dos dados resultantes das entrevistas, na presente pesquisa, foi feita fundamentalmente a partir da revisão teórica já realizada.

\subsection{ENTREVISTA-PILOTO}

Com o intuito de avaliar a técnica de coleta de dados escolhida e corrigir eventuais falhas da mesma, foi realizada uma entrevista em caráter piloto. Para essa tarefa, foi convidado um profissional responsável por fazer a aprovação inicial dos novos projetos de produto em uma empresa de grande porte, fabricante de componente automotivos e localizada na cidade de São Marcos, Rio Grande do Sul. O informante atua como designer e assistente administrativo na organização, demonstrando ter grande influência nas decisões desse âmbito.

A entrevista, em caráter piloto, durou cerca de 35 minutos - menos que o tempo previsto. Isto porque, ao questionar sobre os três últimos projetos em que foram contratados designers, o informante lembrou-se apenas de um, ocorrido há mais de quatro anos. Os demais projetos citados pelo informante foram desenvolvidos por designers que eram funcionários da empresa. Estes últimos casos não foram explorados em profundidade, pela inadequação em relação aos propósitos da pesquisa.

Apesar do caráter de teste dessa entrevista, um cuidado deverá ser tomado na escolha dos informantes da pesquisa de campo a ser desenvolvida, para que se evitem situações semelhantes. Um dos requisitos para a seleção das empresas - de ter a cultura de contratar escritórios de design externos à organização -, deverá ser melhor observado antes do agendamento das entrevistas. 
A percepção do informante acerca do projeto que realmente interessava aos objetivos da pesquisa - o caso ocorrido há mais de quatro anos, foi válida. Mas a mesma poderia ter sido ainda melhor explorada se as informações estivessem mais "frescas" na memória do entrevistado, como ele mesmo comentou durante a entrevista. De qualquer forma, alguns pontos relevantes já puderam ser identificados na percepção do informante, que serão ilustrados a seguir.

O fato de o designer, na ocasião contratado, ter apresentado três opções de segmento do produto para os gestores, e não apenas uma, e ter abordado várias outras questões adicionais além do solicitado - como a embalagem e o número de funcionários envolvidos para a fabricação da peça, foi valorizado pela empresa. Ao ser questionado sobre a etapa projetual que julgava mais relevante, o entrevistado mencionou a importância da apresentação final e o quanto esta foi determinante para a aprovação da proposição apresentada pelo designer contratado, conforme demonstra a seguinte resposta:

“[...] A apresentação final, com certeza... E como ela é feita, sabe? Tem que saber ilustrar bem, assim... no caso, era um estribo... ele ilustrou (o designer) nas camionetes, sabe? Ele ilustrou, colocou os processos industriais bem elaborados, colocou quantos funcionários eram necessários na linha para fazer a montagem, a embalagem do produto, ele mostrou tudo assim, até coisas que ele não deveria ter feito, sabe? Mas, na apresentação final, é ali que se ganha ou não o cliente." (ENTREVISTADO).

Durante a entrevista, também foi possível perceber 0 quanto as características técnicas e de fabricação de um produto são importantes para a empresa, e, no caso mencionado, também foram essenciais para a aprovação da proposição. Neste sentido, o conhecimento do profissional em questão e os desenhos técnicos apresentados por ele, também, foram muito bem avaliados.

O perfil do profissional contratado também demonstrou ter alguma influência no processo de validação, pois, segundo o entrevistado, o designer já tinha familiaridade com a área automotiva, bem como conhecimento técnico sobre a mesma. 


\section{APRESENTAÇÃO DOS RESULTADOS}

Neste capítulo, serão apresentadas as informações decorrentes da pesquisa de campo realizada. Após a transcrição das entrevistas, os dados foram analisados por meio da Análise de Conteúdo, seguindo-se os passos descritos no capítulo do Método, propostos por Moraes (1999). O objetivo geral do trabalho - "compreender a perspectiva do cliente sobre o processo de validação em Design, no segmento moveleiro", bem como os objetivos específicos, nortearam a criação das categorias e subcategorias. A criação das subcategorias foi feita por indução das unidades de análise a temas relacionados aos objetivos. Em seguida, essas subcategorias foram agrupadas por semelhança para a formação das categorias. A seguir, serão descritas as categorias e subcategorias, juntamente com transcrição das principais falas dos participantes.

\subsection{DESCRIÇÃO DAS CATEGORIAS}

A Figura 4 ilustra um esquema que apresenta todas as categorias e subcategorias identificadas nas transcrições das entrevistas. Foram identificadas quatro categorias relacionadas aos objetivos da pesquisa, sendo elas: 1) Evidências de validação relacionadas à proposição apresentada; 2) Evidências de validação relacionadas ao designer contratado; 3) Características do processo projetual relevantes para a validação; e 4) Fatores que influenciam a escolha do cliente sobre o designer a ser contratado. 
Figura 4 - Relação de categorias e subcategorias identificadas na pesquisa

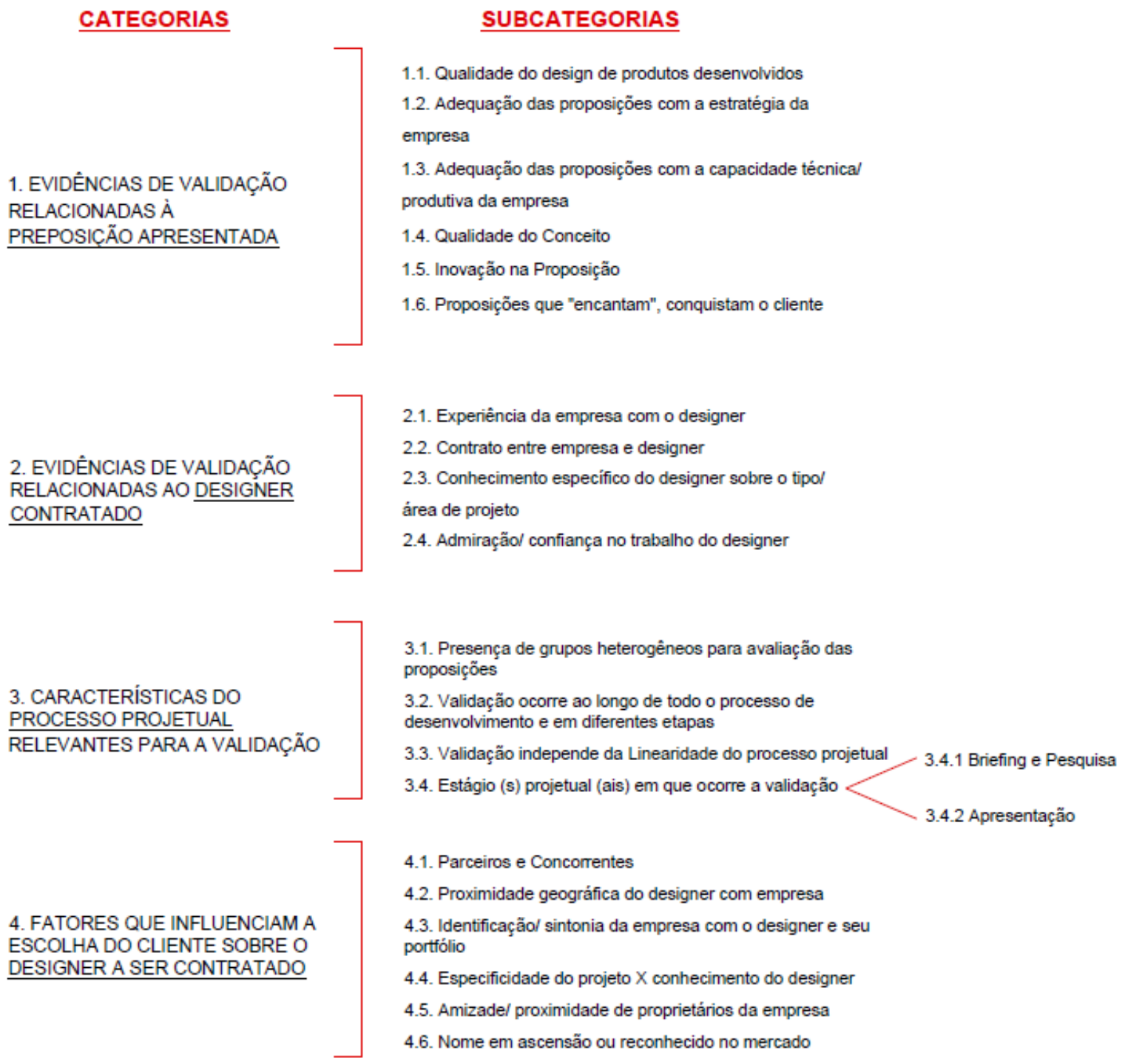

Fonte: Elaborado pela autora.

$\mathrm{Na}$ descrição das categorias e subcategorias, as falas dos participantes transcritas no trabalho foram referenciadas, conforme mostra a Figura 5: 
Figura 5 - Informantes da pesquisa e nomenclatura utilizada nas referenciações

\begin{tabular}{l}
\begin{tabular}{|l|c|}
\hline \multicolumn{2}{|c|}{ Informações dos Participantes } \\
\hline Informante & Local da empresa \\
\hline A - Ane & Bento Gonçalves - RS \\
\hline B - Sergio & Bento Gonçalves - RS \\
\hline C - Grasiela & São Marcos - RS \\
\hline D - Sara & Farroupilha - RS \\
\hline E - Luciane & Caxias do Sul - RS \\
\hline
\end{tabular} \\
$\begin{array}{l}\text { informante } \\
\text { (Grasiela) }\end{array}$ \\
\hline
\end{tabular}

Fonte: Elaborado pela autora.

Os participantes das entrevistas realizadas são os sujeitos que se ocupam das avaliações das novas proposições apresentadas nas empresas eleitas, representando o "cliente" nesta pesquisa. Para desempenhar esse papel decisório, os informantes possuem autoridade dentro das organizações selecionadas, tanto devido aos cargos que exercem - de gerência ou coordenação -, como também devido à sua experiência ou tempo de trabalho junto à empresa. Quase todos os participantes apresentam uma trajetória relativamente longa e crescente nas organizações, sendo que a pessoa que atua há menos tempo, está contratada há três anos e a pessoa com mais tempo de empresa está contratada há 18 anos. $O$ Quadro 1 apresenta essas informações dos participantes da pesquisa. 
Quadro 1 - Informações dos Participantes da Pesquisa

\begin{tabular}{|c|c|c|c|c|}
\hline \multicolumn{5}{|c|}{ INFORMAÇÕES DOS PARTICIPANTES DA PESQUISA } \\
\hline INFORMANTE & $\begin{array}{c}\text { TEMPO DE } \\
\text { ATUAÇÃO NA } \\
\text { EMPRESA }\end{array}$ & $\begin{array}{c}\text { CARGO E } \\
\text { SETOR }\end{array}$ & $\begin{array}{c}\text { RESPONSABILIDADE } \\
\text { DO SETOR }\end{array}$ & $\begin{array}{c}\text { LOCALIZAÇÃO DA } \\
\text { EMPRESA }\end{array}$ \\
\hline A - Ane & 4 anos & $\begin{array}{c}\text { Coordenadora do } \\
\text { Design }\end{array}$ & $\begin{array}{c}\text { Desenvolvimento e } \\
\text { Especificação de Produto }\end{array}$ & Bento Gonçalves - RS \\
\hline B - Sergio & 18 anos & $\begin{array}{c}\text { Gerente do P\&D e } \\
\text { Núcleo de projetos }\end{array}$ & $\begin{array}{c}\text { Pesquisa e } \\
\text { Desenvolvimento de } \\
\text { Produto e Projeto de } \\
\text { Showroom }\end{array}$ & Bento Gonçalves - RS \\
\hline D - Sara & 10 anos & Gerente do "Studio" & $\begin{array}{c}\text { Desenvolvimento de } \\
\text { Produto e Projeto de } \\
\text { showroom }\end{array}$ & São Marcos - RS \\
\hline E - Luciane & 13 anos & $\begin{array}{c}\text { Gerente da Área } \\
\text { Comercial e } \\
\text { Marketing }\end{array}$ & $\begin{array}{c}\text { Pesquisa de produto e } \\
\text { mercado, definição de } \\
\text { demandas para } \\
\text { desenvolvimento }\end{array}$ & Farroupilha - RS \\
\hline
\end{tabular}

Fonte: Elaborado pela autora.

Quase todos os participantes atuam no setor de design, o qual recebe diferentes nomenclaturas nas empresas, como: studio, núcleo de projetos e P\&D (pesquisa e desenvolvimento). Apenas uma entrevistada não está alocada em um setor de design, pois este não existe na empresa. Apesar dessa participante ser responsável pela área comercial e marketing, ainda assim se envolve diretamente com o desenvolvimento de novos produtos.

Das cinco empresas pesquisadas, quatro delas contratam ou já contrataram designers ou arquitetos (que atuam como designers) para desenvolvimento de seus artefatos. Apenas uma delas costuma contratar estilistas e não designers, para o desenvolvimento de superfícies no mobiliário. Como os estilistas, que também são chamados de designers de moda, realizam o desenvolvimento e criação de determinados elementos, esta empresa também preencheu os requisitos que a pesquisa buscava atender.

A seguir, a descrição das categorias e subcategorias identificadas.

1. Categoria: Evidências de validação relacionadas à proposição apresentada

A categoria Evidências de validação relacionadas à proposição apresentada refere-se aos aspectos que motivaram à validação do cliente e que estão 
relacionados a certas características da proposição apresentada ou da negociação entre cliente e designer sobre a proposição. Nesta categoria, foram identificadas seis subcategorias: 1.1 Qualidade do Design de produtos desenvolvidos; 1.2 Adequação das proposições com as estratégias da empresa; 1.3 Adequação das proposições com a capacidade técnica/produtiva da empresa; 1.4 Qualidade do conceito; 1.5 Inovação na proposição; e 1.6 Proposições que "encantam"/conquistam o cliente.

\subsection{Qualidade do Design de produtos desenvolvidos}

Trata-se da propriedade e criatividade que o designer tem para projetar 0 artefato, que resulta em uma qualidade no design de tais artefatos. Quando questionada sobre os motivos da aprovação de um determinado projeto, a informante "E" comenta:

"Então, enfim, é a forma como você tem pra se apropriar dos elementos pra aquela criação. Eu acho que é a criatividade e a inteligência que tá envolvida no momento da criação". (E, 299-300).

Tabela 1 - Subcategoria 1.1 Qualidade do Design de produtos desenvolvidos

1. Categoria: Evidências de validação relacionadas à proposição apresentada

1.1 Subcategoria: Qualidade do Design de produtos desenvolvidos

\begin{tabular}{c|l}
\hline Inf. / Linha & \multicolumn{1}{c}{ Transcrição da fala (unidades de análise) } \\
\hline B,178-181 & $\begin{array}{l}\text { (...) Eu acho que com alguns produtos, sim! Alguns produtos que são... alguns itens que a gente } \\
\text { vê, tipo, mais icônicos da linha, né? Como tem o armário Theca, que é aquela cristaleira toda em } \\
\text { alumínio e vidro. Então, alguns produtos que realmente nos surpreenderam, né? (...). }\end{array}$ \\
E, $299-300$ & $\begin{array}{l}\text { (...) Então, enfim, é a forma como você tem pra se apropriar dos elementos pra aquela criação. } \\
\text { Eu acho que é a criatividade e a inteligência que tá envolvida no momento da criação. (...). }\end{array}$ \\
\hline
\end{tabular}

Fonte: Elaborado pela autora.

\subsection{Adequação das proposições com as estratégias da empresa}

Alguns informantes falam sobre a importância das proposições apresentadas estarem coerentes com a(s) estratégia(s) da empresa, a qual inclui decisões ligadas ao produto e ao portfólio, à identidade da marca, ao perfil do cliente, aos objetivos/metas da empresa. Falas como a da informante "A" demonstram o quanto esses fatores são levados em conta durante a avaliação sobre um determinado projeto: 
“(...) Hoje sempre que a gente analisa um projeto, a gente sempre faz algumas perguntas básicas e dependendo da resposta, é o que define se ele é ou se ele não é... Bom, desde a questão, o quanto isso vai entregar para a minha marca, o quanto isso vai posicionar a minha marca, 0 quanto isso vai trazer de faturamento pra minha marca, o quanto isso vai impactar na minha fábrica. (...)”. (A, 334-340).

Tabela 2 - Subcategoria 1.2 Adequação das proposições com as estratégias da empresa

1. Categoria: Evidências de validação relacionadas à proposição apresentada 1.2 Subcategoria: Adequação das proposições com as estratégias da empresa

\begin{tabular}{|c|c|}
\hline Inf. / Linha & Transcrição da fala (unidades de análise) \\
\hline$E, 418-419$ & $\begin{array}{l}\text { (...) Tu percebe que o produto tem a cara da marca, tem tudo a ver com a marca e a partir dali } \\
\text { já saiu daqui com contrato assinado, sabe? (...). }\end{array}$ \\
\hline$B, 417-422$ & $\begin{array}{l}\text { (...) Na realidade, é que assim, que a gente vê como bem importante, é que a realidade daquilo } \\
\text { que eles estão nos propondo, é que tenha muito a ver com a identidade da empresa, identidade } \\
\text { do produto, identidade marca (...). Porque não adianta eles apresentarem o projeto sem } \\
\text { conhecer a empresa a fundo ou aonde a gente pode chegar, porque não vai ter sintonia, né? } \\
\text { (...). }\end{array}$ \\
\hline A, $334-340$ & $\begin{array}{l}\text { (...) Hoje sempre que a gente analisa um projeto, a gente sempre faz algumas perguntas } \\
\text { básicas e, dependendo da resposta, é o que define se ele é ou se ele não é... Bom, desde a } \\
\text { questão, o quanto isso vai entregar para a minha marca, o quanto isso vai posicionar a minha } \\
\text { marca, o quanto isso vai trazer de faturamento pra minha marca, o quanto isso vai impactar na } \\
\text { minha fábrica. Então, são coisas que a gente se pergunta, pra entender se... pra fazer o } \\
\text { primeiro filtro do briefing. Posicionou? Está coerente com o posicionamento da marca? É um } \\
\text { diferencial comercialmente?(...). }\end{array}$ \\
\hline C, $59-62$ & $\begin{array}{l}\text { (...) Outra coisa é a questão do conceito. Nem sempre o escritório conhece o conceito da } \\
\text { empresa, o público da empresa. Até chegar nesse nível, você percorreu um longo tempo, fez } \\
\text { uma série de propostas, e não chega no resultado. (...). }\end{array}$ \\
\hline
\end{tabular}

Fonte: Elaborado pela autora.

\subsection{Adequação das proposições com a capacidade técnica/produtiva da} empresa

De acordo com alguns informantes, é de extrema importância que as proposições apresentadas pelos designers sejam coerentes com a capacidade fabril da empresa, que estas sejam passíveis de serem produzidas nas suas condições existentes e em escala industrial. Alguns designers, segundo os entrevistados, conseguem "enxergar" essa capacidade fabril, como exprime a seguinte fala:

“(...) eu até comentei que foi crucial, realmente foi a questão do 'designer $X$ ', né? Do 'designer $X$ ' entender muito a produção né, então, ao visitar a empresa, ele conseguiu enxergar o potencial que a minha produção tinha de fazer, mais as dificuldades, e quando apresentou o produto, ele apresentou certinho dentro daquilo que tinha possibilidade... (...)". (D, 628 -639). 
Tabela 3 - Subcategoria 1.3 Adequação das proposições com a capacidade técnica/produtiva da empresa

\begin{tabular}{|c|c|}
\hline \multicolumn{2}{|r|}{$\begin{array}{l}\text { 1. Categoria: Evidências de validação relacionadas à proposição apresentada } \\
\text { 1.3 Subcategoria: Adequação das proposições com a capacidade técnica/produtiva da } \\
\text { empresa }\end{array}$} \\
\hline Inf. / Linha & Transcrição da fala (unidades de análise) \\
\hline$A, 183-189$ & $\begin{array}{l}\text { (...) O que é crucial para nós, é a questão de ser ou não ser produtivo. "Eu posso ou não posso } \\
\text { produzir?", isso define o meu projeto. Se não tem como produzir num modelo fabril adequado, a } \\
\text { gente já descarta, porque enfim, eu não posso entregar para o mercado... que é muito lindo, } \\
\text { conta lindas histórias, mas que é impossível ser produzido, eu vou produzir apenas para a } \\
\text { Daniele e não vou produzir pra mais ninguém. (...). } \\
\text { (...) eu até comentei que foi crucial, realmente foi a questão do "designer x", né? Do "designer x" } \\
\text { entender muito a produção né, então, ao visitar a empresa, ele conseguiu enxergar o potencial } \\
\text { que a minha produção tinha de fazer, mais as dificuldades, e quando apresentou o produto, ele } \\
\text { apresentou certinho dentro daquilo que tinha possibilidade... (...) Que tinha capacidade produtiva } \\
\text { pra época, porque a gente tem... algo que a gente tem que pensar também na questão de } \\
\text { produtos é... eu tenho um produto que o desenho é lindo, eu amei/adorei, mas eu não tenho a } \\
\text { capacidade tecnológica ou a minha produção não tá preparada pra executar esse produto (...). }\end{array}$ \\
\hline
\end{tabular}

Fonte: Elaborado pela autora.

\subsection{Qualidade do conceito}

Esta subcategoria refere-se à propriedade que o designer tem em apresentar um conceito consistente de projeto. Segundo os informantes, o projeto precisa "fazer sentido" ou "contar histórias" criativas. Apresentar um projeto cujo conceito apresenta qualidade pode influenciar a validação de uma proposição, como exemplifica a fala da informante " $\mathrm{C}$ ":

“(...) Eu acho que quando eles conseguiram apresentar uma proposta que teve um conceito. (...) Aí a gente conseguiu realmente, né... sabe? Quando eles conseguiram contextualizar, envolver e trabalhar uma temática. (...)". (C, 73-76). 
Tabela 4 - Subcategoria 1.4 Qualidade do conceito

\section{Categoria: Evidências de validação relacionadas à proposição apresentada}

1.4 Subcategoria: Qualidade do conceito

\begin{tabular}{l|l}
\hline Inf. / Linha & \multicolumn{1}{c}{ Transcrição da fala (unidades de análise) } \\
\hline C, 73 - 76 & $\begin{array}{l}\text { (...) Eu acho que quando eles conseguiram apresentar uma proposta que teve um conceito. (...) } \\
\text { Aí a gente conseguiu realmente, né, sabe? Quando eles conseguiram contextualizar, envolver e } \\
\text { trabalhar uma temática. (...). }\end{array}$ \\
A, 102 - 107 - 295 & $\begin{array}{l}\text { (...) Eu acho que foi até na apresentação inicial da ideia do produto assim, do, que nem a última } \\
\text { coleção que ela trabalhou, ela trabalhou a ideia do desenvolvimento dela foi algumas.... (..) ela se } \\
\text { baseou muito em algumas culturas né, regionais, então, por exemplo, tem um desenho que ela } \\
\text { se inspirou na bombacha do gaúcho, aquela faixa lateral e ela ampliou aquele desenho... (...). }\end{array}$ \\
$\begin{array}{l}\text { (...) porque eles vinculam muito a histórias. O último, por exemplo, o "designer Y", ele quis fazer... } \\
\text { a ideia dele era desenvolver uma madeira moderna. Se tu olhar o desenho do "designer Y", tu } \\
\text { não vai vincular a uma madeira, tu vai vincular a um tecido. A ideia dele era resgatar os anos } 60, \\
\text { que o homem foi a Lua. A ideia dele era desenvolver a madeira do futuro. Então eles conseguem } \\
\text { vender histórias muito boas! (...). }\end{array}$ \\
\hline
\end{tabular}

Fonte: Elaborado pela autora.

\subsection{Inovação na proposição}

A capacidade de apresentar uma proposta inovadora no contexto ou segmento do projeto é citada como uma evidência para a validação de uma proposição. Uma proposta inovadora, normalmente, gera novos conceitos, valores e possibilidades para a empresa. A informante "E", por exemplo, fala sobre o novo conceito (in shade) trazido pelo designer com a proposição:

“(...) Eu acho que o in-shade é uma das coisas que foi o designer que trouxe, nós levamos o conceito a debate interno e se entendeu que realmente era uma coisa inovadora e passamos a apostar nessa proposta, né? (...)". (E, 208-210).

Tabela 5 - Subcategoria 1.5 Inovação na proposição

\section{Categoria: Evidências de validação relacionadas à proposição apresentada}

1.5 Subcategoria: Inovação na proposição

\begin{tabular}{|c|c|}
\hline Inf. / Linha & Transcrição da fala (unidades de análise) \\
\hline$E, 323-325$ & $\begin{array}{l}\text { (...) Então mudou o conceito de sofá dentro da linha da "empresa E". Acho que isso foi um } \\
\text { determinante para o sucesso dele. (...) }\end{array}$ \\
\hline$E, 313-318$ & $\begin{array}{l}\text { (...) Sim, o polo foi uma inovação dentro da linha de estofados da "empresa E". Tanto em termos } \\
\text { de estética, eu diria, inclusive de materiais. Então, como eu te falei, pluma de ganso era um } \\
\text { material que a gente não utilizava, o couro a gente já utilizava, mas de uma forma diferente: não } \\
\text { da forma como eles aplicaram no polo. Então existem alguns elementos ali que, que eu acho que } \\
\text { determinaram o sucesso do produto. (...). }\end{array}$ \\
\hline$E, 208-210$ & $\begin{array}{l}\text { (...) Eu acho que o in-shade é uma das coisas que foi o designer que trouxe, nós levamos o } \\
\text { conceito a debate interno e se entendeu que realmente era uma coisa inovadora e passamos a } \\
\text { apostar nessa proposta, né? (...). }\end{array}$ \\
\hline
\end{tabular}

Fonte: Elaborado pela autora. 


\subsection{Proposições que "encantam"/conquistam o cliente}

Quando uma proposição de design "encanta" ou conquista o cliente, existe uma aceitação por motivos emocionais, difíceis de serem mensurados. A informante " $D$ ", por exemplo, menciona que, além do encantamento, é necessário o desejo de compra do artefato - por parte das pessoas que avaliam -, para que este seja validado:

“(...) Então eu digo para o 'designer $X$ ': se quando ficar pronto esse produto, a gente olhar e se encantar, e dizer assim, eu compraria, a gente coloca em linha. (...) Se a gente não chegar nesse ponto, não ficar convencido, então deixa ele lá... (...)". (D, 507 - 512).

Tabela 6 - Subcategoria 1.6 Proposições que "encantam"/conquistam o cliente

1. Categoria: Evidências de validação relacionadas à proposição apresentada

1.6 Subcategoria: Proposições que "encantam"/conquistam o cliente

\begin{tabular}{|c|l|}
\hline Inf. / Linha & \multicolumn{1}{|c}{ Transcrição da fala (unidades de análise) } \\
\hline $\mathrm{D}, 507-512$ & $\begin{array}{l}\text { (...) Então eu digo para o "designer X”: se quando ficar pronto esse produto, a gente olhar e se } \\
\text { encantar, e dizer assim, eu compraria, a gente coloca em linha. (...) Se a gente não chegar nesse } \\
\text { ponto, não ficar convencido, então deixa ele lá... (...). }\end{array}$ \\
$\mathrm{D}, 518$ - 519 & $\begin{array}{l}\text { (...) Eu acho que é a primeira etapa, né. Se não conquistar a gente, a gente não vai dizer assim } \\
\text { ó: "adooorei", teria na minha casa, hoje a gente não lança, né? (...). }\end{array}$ \\
\hline
\end{tabular}

Fonte: Elaborado pela autora.

2. Categoria: Evidências de validação relacionadas ao designer contratado

A categoria Evidências de validação relacionadas ao designer contratado refere-se às situações em que a validação de uma proposição tem relação com o profissional contratado, seja por seu perfil ou pela relação entre este profissional e a empresa-cliente. A categoria foi dividida nas seguintes subcategorias: 2.1 Experiência da empresa com o designer; 2.2 Contrato entre a empresa e o designer; 2.3 Conhecimento específico do designer sobre o tipo/área de projeto; e 2.4 Admiração/confiança no trabalho do designer.

\subsection{Experiência da empresa com o designer}

A experiência que o designer adquire em uma empresa, pelo tempo de trabalho ou número de projetos desenvolvidos, por exemplo, influencia 
positivamente na validação de uma proposição. Segundo a fala da informante "E", existe uma facilidade com os designers que trabalham há mais tempo na empresa:

“(...) Existe uma facilidade com os profissionais que têm mais tempo de casa (...) isso tudo são experiências que o profissional vai adquirindo que vão resultar num trabalho mais acertado. (...)". (E, 115-120).

Tabela 7 - Subcategoria 2.1 Experiência da empresa com o designer

2. Categoria: Evidências de validação relacionadas ao designer contratado

2.1 Subcategoria: Experiência da empresa com o designer

\begin{tabular}{c|l}
\hline Inf. / Linha & \multicolumn{1}{c}{ Transcrição da fala (unidades de análise) } \\
\hline E, 115 - 120 & $\begin{array}{l}\text { (...) Existe uma facilidade com os profissionais que têm mais tempo de casa. Então posso citar a } \\
\text { "designer X" e o "designer Y" que estão há mais tempo que o "designer Z". Mas tem outros que } \\
\text { têm menos tempo que o "designer Z", mas que também já tem um conhecimento grande, tanto } \\
\text { do processo fabril, do processo como a marca atua, do produto, aonde que o produto vai tá, } \\
\text { quem é o nosso cliente, então... isso tudo são experiências que o profissional vai adquirindo que } \\
\text { vão resultar num trabalho mais acertado. (...). }\end{array}$ \\
\hline
\end{tabular}

Fonte: Elaborado pela autora.

\subsection{Contrato entre a empresa e o designer}

O contrato firmado entre a empresa e o designer parece influenciar na validação de uma proposição, conforme mostra a fala do informante "E":

“(...) desde o começo, quando a gente fez o contato e decidiu por desenvolver uma linha, a gente já assinou um contrato anual com eles pra desenvolvimento, né, então... (...) Foi uma decisão muito antes do que eles nos apresentarem um produto em si ou uma ideia, né! (...)”. (B, $184-$ 189).

A fala exprime a ideia de que o contrato anual com o escritório conduz a um posicionamento favorável com relação àquilo que é apresentado.

Tabela 8 - Subcategoria 2.2 Contrato entre a empresa e o designer

2. Categoria: Evidências de validação relacionadas ao designer contratado

2.2 Subcategoria: Contrato entre a empresa e o designer

\begin{tabular}{c|l}
\hline Inf. / Linha & \multicolumn{1}{c}{ Transcrição da fala (unidades de análise) } \\
\hline $\mathrm{B}, 184-189$ & $\begin{array}{l}\text { (...) desde o começo, quando a gente fez o contato e decidiu por desenvolver uma linha, a gente } \\
\text { já assinou um contrato anual com eles pra desenvolvimento, né, então... (...) Foi uma decisão } \\
\text { muito antes do que eles nos apresentarem um produto em si ou uma ideia, né! (...). }\end{array}$ \\
\hline
\end{tabular}

Fonte: Elaborado pela autora. 


\subsection{Conhecimento específico do designer sobre o tipo/ área de projeto}

As falas de alguns informantes demonstram que a validação é influenciada pelo conhecimento que o profissional apresenta sobre o tipo de projeto ou segmento para o qual é requisitado. Se um profissional possui expertise sobre a área de projeto na qual está atuando, existe uma facilidade em conduzir o processo, como exemplifica a seguinte fala:

“(...) É, então aquela questão que nem a gente comentou do 'designer $X$ ' né: 'Oh, aqui quem sabe a gente bota uma espuma assim, a gente coloca uma percinta tal, a gente coloca uma manta tal pra dar um fofo'. Então ele já tá falando a linguagem do pessoal técnico. (...)”. (D, 422-425).

Tabela 9 - Subcategoria 2.3 Conhecimento específico do designer sobre o tipo/área de projeto

\section{Categoria: Evidências de validação relacionadas ao designer contratado}

2.3 Subcategoria: Conhecimento específico do designer sobre o tipo/área de projeto

\begin{tabular}{|c|c|}
\hline Inf. / Linha & Transcrição da fala (unidades de análise) \\
\hline C, $37-44$ & $\begin{array}{l}\text { (...) Mas como um escritório que também não tem um foco só de mobiliário, então nós } \\
\text { percebemos que houve algumas dificuldades, o processo foi bem longo, a gente teve que } \\
\text { interromper por diversos momentos e pedir outras coisas. Então, foi bem complicado...Tanto } \\
\text { que assim, essa linha ainda não foi colocada no mercado, porque justamente tem vários ajustes } \\
\text { e a gente acabou pegando outras pessoas, outros profissionais, outras pessoas que trabalham } \\
\text { com isso ou os próprios fornecedores de alguns elementos, de algumas coisas que também } \\
\text { tinham um pouco mais de conhecimento do que esse próprio escritório que criou... (...). }\end{array}$ \\
\hline$D, 422-425$ & $\begin{array}{l}\text { (...) É, então aquela questão que nem a gente comentou do "designer X" né: "Oh, aqui quem } \\
\text { sabe a gente bota uma espuma assim, a gente coloca uma percinta tal, a gente coloca uma } \\
\text { manta tal pra dar um fofo". Então ele já tá falando a linguagem do pessoal técnico. (...). }\end{array}$ \\
\hline D, $383-388$ & $\begin{array}{l}\text { (...) Exatamente! Né, então, o estofado pra ela, era relativamente novo. É claro, toda pessoa } \\
\text { precisa da experiência pra chegar lá na frente né, é uma coisa natural, seja em qualquer área } \\
\text { né... Mas o processo fica diferente, então você acaba não ficando tão tranquila... (...) O } \\
\text { processo fica demorado também. (...). }\end{array}$ \\
\hline A, $258-261$ & $\begin{array}{l}\text { (...) Exato! E às vezes nem ele, porque ele não tem essa mesma visão que nós temos no } \\
\text { moveleiro. Então ele tem uma visão vinculada à moda, que às vezes quando tu vai transferir } \\
\text { essa ideia para o papel, tu não vai ter exatamente o que ele estava imaginando. E aí são os } \\
\text { pontos de... não digo de conflito, são os pontos de "vai e volta" (...). }\end{array}$ \\
\hline
\end{tabular}

Fonte: Elaborado pela autora.

\subsection{Admiração/confiança no trabalho do designer}

Algumas falas de informantes demonstram que os sentimentos de admiração e/ou confiança que o cliente tem no designer influenciam positivamente na validação de uma proposição, conforme mostra a fala do informante "B":

“(...) a gente tava apostando no projeto que a gente tava fazendo com ela, mas diante do que nós pesquisamos e conhecemos sobre o trabalho dela, a gente não teve insegurança não (...)”. (B, 274-276) 
Tabela 10 - Subcategoria 2.4 Admiração/ confiança no trabalho do designer

2. Categoria: Evidências de validação relacionadas ao designer contratado

2.4 Subcategoria: Admiração/confiança no trabalho do designer

\begin{tabular}{c|l}
\hline Inf. / Linha & \multicolumn{1}{c}{ Transcrição da fala (unidades de análise) } \\
\hline $\mathrm{B}, 274-276$ & $\begin{array}{l}\text { (...) a gente tava apostando no projeto que a gente tava fazendo com ela, mas diante do que } \\
\text { nós pesquisamos e conhecemos sobre o trabalho dela, a gente não teve insegurança não (...). }\end{array}$ \\
$\mathrm{B}, 146-148$ & $\begin{array}{l}\text { (...) no momento que teve essa aproximação, a gente começou a pesquisar mais e, assim, e } \\
\text { depois a gente começou a se interessar e admirar o trabalho deles (...). }\end{array}$ \\
\hline
\end{tabular}

Fonte: Elaborado pela autora.

3. Categoria: Características do processo projetual relevantes para à validação

A categoria Características do processo projetual relevantes à validação trata de alguns aspectos observados no processo de desenvolvimento de novos produtos que são pertinentes ao estudo da validação de uma proposição. Esta categoria divide-se nas seguintes subcategorias: 3.1 Presença de grupos heterogêneos para a avaliação das proposições; 3.2 Validação ocorre ao longo de todo o processo de desenvolvimento e em diferentes etapas; 3.3 Validação independe da linearidade do processo projetual; e 3.4 Estágio (s) Projetual (ais) em que ocorre $(\mathrm{m})$ a Validação. Essa última subcategoria divide-se em: 3.4.1 Briefing e Pesquisa; e 3.4.2 Apresentação.

\subsection{Presença de grupos heterogêneos para a avaliação das proposições}

De acordo com algumas falas, percebe-se que o processo de validação nas empresas tem a participação e contribuição de diferentes setores e profissionais, além do design, que na maioria das vezes, formam grupos para análise das proposições. Cada profissional contribui com a sua expertise para a qualificação das propostas. A informante " $\mathrm{D}$ " comenta sobre um dos comitês formado para avaliação dos estágios finais do projeto:

"(...) Esse último é o "fulano", que é o designer, aí eu que sou do mercado né, é o diretor industrial né, pra ver se tem que fazer os últimos acertos, o quê que gera na produção e o diretor da empresa, por estar mais ciente, por já ter aquela coisa do conhecimento do mercado, né, então, a gente analisa tudo bem direitinho (...)". (D, 561 -564). 
Tabela 11 - Subcategoria 3.1 Presença de grupos heterogêneos para a avaliação das proposições

\section{Categoria: Características do processo projetual relevantes para a validação}

3.1 Subcategoria: Presença de grupos heterogêneos para a avaliação das proposições

\begin{tabular}{|c|c|}
\hline Inf. / Linha & Transcrição da fala (unidades de análise) \\
\hline$C, 175-184$ & $\begin{array}{l}\text { (...) Nós temos o comitê de produtos (...). Eu dou a opinião... "Ah não... esse é legal } \\
\text { esteticamente e vai ficar bonito", então eu participo com essa opinião. A pessoa da engenharia } \\
\text { participa da questão..." Ah não, funciona realmente, vai funcionar" O Marketing: "Ah É legal } \\
\text { trabalhar esse produto porque ele tá realmente linkado com o conceito da marca, onde ele vai } \\
\text { estar posicionado no mercado" E o diretor é quem vai dar... a palavra final também, né? (...). }\end{array}$ \\
\hline$D, 561-564$ & $\begin{array}{l}\text { (...) Esse último é o "fulano", que é o designer, aí eu que sou do mercado né, é o diretor } \\
\text { industrial né, pra ver se tem que fazer os últimos acertos, o quê que gera na produção e o diretor } \\
\text { da empresa, por estar mais ciente, por já ter aquela coisa do conhecimento do mercado, né, } \\
\text { então, a gente analisa tudo bem direitinho (...). }\end{array}$ \\
\hline E, $31-38$ & $\begin{array}{l}\text { (...) A aprovação, como ela funciona hoje, tá: não é uma pessoa, única, que define, que aprova } \\
\text { uma criação, que aprova uma demanda. Então, as demandas saem, claro, os levantamentos } \\
\text { todos dessa área, que é o Studio, mas eles passam, obviamente, por uma avaliação... da } \\
\text { direção de mercado que é a direção que coordena o Studio também. E uma troca com algumas } \\
\text { opiniões de lojistas, tá. Então a gente tem um comitê formatado com representantes de algumas } \\
\text { lojas e a gente consegue trocar esse tipo de informação no intuito de acertar cada vez mais um } \\
\text { lançamento. (...). }\end{array}$ \\
\hline A , 23-27 & $\begin{array}{l}\text { (...) A equipe de Design estrutura todo o projeto, junto depois com a área de engenharia, que faz } \\
\text { prototipagem do produto, afirma que aquela ideia tem consistência. A gente como Design leva } \\
\text { isto para uma reunião de diretoria ou então os gestores envolvidos e os diretores envolvidos e o } \\
\text { nosso diretor executivo, aonde é tomada a decisão se o projeto vai ou não vai acontecer. (...). }\end{array}$ \\
\hline$B, 330-336$ & $\begin{array}{l}\text { (...) Na verdade, assim, a gente tem dentro do } P \text { \& } D \text { assim no desenvolvimento, a gente tem } \\
\text { tipo um comitê de desenvolvimento que a gente chama. Desse comitê faz parte então, o } \\
\text { responsável pela área comercial, o responsável por marketing, todas as pessoas do P \& } D \text {, uma } \\
\text { pessoa do núcleo de projetos, no caso o "arquiteto X" aí né, e a direção também né. Então a } \\
\text { gente sempre, quando chega numa análise crítica do projeto, alguma coisa assim, a gente reúne } \\
\text { esse comitê então pra aprovação, pra dar andamento no projeto e tal. (...). }\end{array}$ \\
\hline A, $301-306$ & $\begin{array}{l}\text { (...) Todas as áreas que tem envolvimento direto com o projeto, que começa com o } \\
\text { desenvolvimento de produto, colaboração na área de marketing, então projetos mais simples } \\
\text { não, projetos mais complexos nós temos a área de marketing, a área de engenharia, que é } \\
\text { responsável por toda a parte de cadastro, roteiro de produção e prototipagem, a etapa de CPL, } \\
\text { que é o nosso controle de produção. Então analisar todos os impactos fabris que esse projeto } \\
\text { vai ter. Custos e compras (...). }\end{array}$ \\
\hline
\end{tabular}

Fonte: Elaborado pela autora.

3.2 Validação ocorre ao longo de todo o processo de desenvolvimento e em diferentes etapas

Esta subcategoria diz respeito à ideia de que a validação de proposições nas empresas ocorre ao longo do processo de desenvolvimento de produto e em momentos distintos: desde a contratação do profissional, por exemplo, até o momento em que o produto chega às lojas. A informante " $A$ " explica que um projeto passa por um sistema de documentação, bem como uma série de filtros antes de chegar ao mercado: 
“(...) A aprovação ocorre no decorrer do projeto. Então toda ela, ela passa por sistema de documentação, que tem etapas. Todos esses filtros que eu te comentei são documentados e são assinados, então ele só passa para a próxima etapa se foi aprovado no filtro anterior. (...)". (A, $292-$ 297).

Tabela 12 - Subcategoria 3.2 Validação ocorre ao longo de todo o processo de desenvolvimento e em diferentes etapas

\begin{tabular}{|c|c|}
\hline \multicolumn{2}{|c|}{$\begin{array}{l}\text { 3. Categoria: Características do processo projetual relevantes para a validação } \\
\text { 3.2 Subcategoria: Validação ocorre ao longo de todo o processo de desenvolvimento e em } \\
\text { diferentes etapas }\end{array}$} \\
\hline Inf. / Linha & Transcrição da fala (unidades de análise) \\
\hline A, $292-297$ & $\begin{array}{l}\text { (...) A aprovação ocorre no decorrer do projeto. Então toda ela, ela passa por sistema de } \\
\text { documentação, que tem etapas. Todos esses filtros que eu te comentei são documentados e } \\
\text { são assinados, então ele só passa para a próxima etapa se foi aprovado no filtro anterior. } \\
\text { Então quando eu entreguei ela, o produto para o mercado, foram feitas todas as análises e } \\
\text { todos os filtros necessários pra entregar o produto coerente para o mercado. (...). }\end{array}$ \\
\hline E, $157-160$ & $\begin{array}{l}\text { (...) Vamos supor que a gente tivesse apresentado a Capadócia para o comitê e o comitê } \\
\text { encontrou uma série de dificuldades e de problemas. A gente iria avaliar essas questões } \\
\text { citadas, daqui a pouco ia reconfigurar o produto. Então é uma validação que ela vai } \\
\text { acontecendo ao longo do processo. (...). } \\
\text { (...) Então o protótipo é uma validação daquela proposta. Seja ela técnica, de detalhes... } \\
\text { porque detalhes tu não avalia na criação. (...). }\end{array}$ \\
\hline E, $194-197$ & $\begin{array}{l}\text { (...) Eu te diria que não é um momento específico, tá? Mas... tem alguns pontos que eles são } \\
\text { fundamentais, tá? É o envolvimento com todas as áreas, quando a gente fala da avaliação, até } \\
\text { do comitê, enfim, existe um envolvimento com o processo. Então existe uma... uma } \\
\text { determinada importância que se dá pra esse... pra esse envolvimento também. (...). }\end{array}$ \\
\hline
\end{tabular}

Fonte: Elaborado pela autora.

\subsection{Validação independe da linearidade do processo projetual}

Segundo as falas de alguns informantes, a validação de uma proposição parece não estar associada a um processo projetual sequencial, com etapas distintas e previsíveis. A validação pode ocorrer de forma espontânea, independentemente da metodologia do processo projetual. A fala da informante "E" relata um caso em que o designer apresentou a ideia de um produto, antes mesmo de ter tratado sobre o briefing com a empresa:

“(...) Não foi passado um briefing e ele veio com o produto." (...) E ele apresentou o produto e eu disse... 'faz esse produto porque eu acho que...' e aconteceu porque realmente a poltrona, enfim, estampou campanha institucional, tá nas mídias sociais, assim, é um sucesso.(...)". (E, 422-429). 
Tabela 13 - Subcategoria 3.3 Validação independe da linearidade do processo projetual

3.Categoria: Características do processo projetual relevantes para a validação

3.3 Subcategoria: Validação independe da linearidade do processo projetual

\begin{tabular}{c|l}
\hline Inf. / Linha & \multicolumn{1}{c}{ Transcrição da fala (unidades de análise) } \\
\hline A, 99-101 & $\begin{array}{l}\text { (...) E sim, tem momentos que ele viaja mais, quando ele tá no mundo dele. E aí do nada, } \\
\text { parece que ele olha e enxerga "encontrei a solução dos problemas" (...). } \\
\text { (...) "Briefa", cria e entrega, não é esse fluxo perfeito. Tanto que o projeto do "designer X", ele } \\
\text { começou com uma ideia, que nos vendeu também, porque ele fez um vínculo direto ao que } \\
\text { estava ocorrendo na moda, o que ele iria levar para as passarelas. Então ele nos vendeu uma } \\
\text { ideia, a gente trabalhou sobre uma ideia por uns 2 ou 3 meses. E quando o projeto estava } \\
\text { prestes a ser entregue, ele mudou a ideia, ele mudou totalmente a ideia. E foi quando ele nos } \\
\text { trouxe essa (...) E aí a gente voltou todo o projeto pra trás, em tempo recorde, e a gente } \\
\text { desenvolveu tudo de novo, em cima de outra superfície, outro desenho de superfície. (...). } \\
\text { (...) Não foi passado um briefing e ele veio com o produto. Ali foi, por isso que eu te disse que } \\
\text { foi muito engraçado. Porque ele veio pra uma conversa, pra gente se conhecer, saber como é } \\
\text { que era o processo de trabalho dele, enfim, né? (...) E ele apresentou o produto e eu disse... } \\
\text { "faz esse produto porque eu acho que..." e aconteceu porque realmente a poltrona, enfim, } \\
\text { estampou campanha institucional, tá nas mídias sociais, assim, é um sucesso. (...). } \\
\text { (...) Foi muito espontâneo, foi algo que não seguiu processo nenhum (...). }\end{array}$ \\
\hline
\end{tabular}

Fonte: Elaborado pela autora.

\subsection{Estágio(s) Projetual(ais) em que ocorre(m) a validação}

A subcategoria Estágio(s) Projetual(ais) em que ocorre $(\mathrm{m})$ a validação tratase de estágios do processo projetual de design, identificados nas falas, e que são relevantes para a validação de proposições, podendo ser estágios aos quais o cliente dá maior importância ou que afetam o resultado do projeto. Nesta subcategoria, foram identificados dois outros grupos: 3.4.1 Briefing e Pesquisa e 3.4.2 Apresentação.

\subsubsection{Briefing e Pesquisa}

Compõem a fase inicial e de análise de uma nova proposição, onde são definidas as demandas, contexto, escopo, público e demais detalhes que envolvem o projeto. Segundo os informantes, é uma fase de extrema importância para que o projeto seja validado posteriormente. Alguns informantes falam apenas do briefing $\mathrm{e}$ outros, falam do briefing e da pesquisa juntos, como exprime a seguinte fala:

“(..) Acho que em primeiro lugar é o briefing, né? Tu ter realmente bem certinho o que tu deseja, o que tu quer fazer, ter esse foco de qual a proposta desse produto. E, depois disso, com certeza é a pesquisa, fazer uma boa pesquisa... o início! Se você conseguir fazer um início bem feito, tendo o conhecimento adequado, sabendo direitinho qual a proposta, acredito que tem muito mais chance. (...)". (C, $193-197)$. 
Tabela 14 - Subcategoria 3.4.1 Briefing e Pesquisa

3.Categoria: Características do processo projetual relevantes para a validação

3.4 Subcategoria: Estágio(s) Projetual(ais) em que ocorre $(\mathrm{m})$ a validação

3.4.1 Subcategoria: Briefing e Pesquisa

\begin{tabular}{|c|l|}
\hline Inf. / Linha & \multicolumn{1}{c}{ Transcrição da fala (unidades de análise) } \\
\hline B, 167 - 172 & $\begin{array}{l}\text { (...) Ah, eu acho que foi desde o começo, sabe? Porque no momento em que nós passamos o } \\
\text { briefing, que nós queríamos desenvolver com eles um produto (...) eu acho que desde o } \\
\text { momento que a gente passou esse briefing eles entenderam bem o conceito do que nós } \\
\text { queríamos, e também as particularidades da empresa. E tudo que eles nos apresentaram, nós } \\
\text { fomos de acordo assim, sempre gostando (...). }\end{array}$ \\
$\mathrm{E}, 180-187$ & $\begin{array}{l}\text { (...) Acho que é o atendimento ao briefing. É... Hoje, o que que acontece: independente de tu } \\
\text { ter o profissional que tu contrata, que tem o foco para esse mercado, que já conhece teu } \\
\text { cliente, que já conhece o processo da tua empresa, que conhece como o produto vai ser } \\
\text { exposto, o comitê das lojas que tá lá na ponta, todo o dia com o cliente, independente disso, } \\
\text { quem é soberano na definição e nas demandas é a marca. (...) Então, a demanda, ela nasce } \\
\text { aqui. Eu acho que soberano é quem define (...). }\end{array}$ \\
$\mathrm{C}, 193-197$ & $\begin{array}{l}\text { (...) Acho que em primeiro lugar é o briefing, né? Tu ter realmente bem certinho o que tu } \\
\text { deseja, o que tu quer fazer, ter esse foco de qual a proposta desse produto. E depois disso } \\
\text { com certeza é a pesquisa, fazer uma boa pesquisa... o início! Se você conseguir fazer um } \\
\text { início bem feito, tendo o conhecimento adequado, sabendo direitinho qual a proposta, acredito } \\
\text { que tem muito mais chance. (...). }\end{array}$ \\
\hline
\end{tabular}

Fonte: Elaborado pela autora.

\subsubsection{Apresentação}

Quando o designer apresenta suas ideias ao cliente, normalmente o projeto encontra-se na fase de síntese. A apresentação é o momento que o designer tem de mostrar os materiais físicos e virtuais já elaborados e também é o momento que ele tem para argumentar e convencer os atores envolvidos sobre suas ideias. Esta subcategoria é composta por unidades de análise relacionadas a elementos técnicos e outras ligadas a dinâmicas sociais da apresentação.

Os elementos técnicos são os elementos físicos e virtuais utilizados na apresentação, bem como as técnicas de representação de projeto utilizadas pelo designer, os quais são citados como importantes para a validação de uma proposição. As dinâmicas sociais são os movimentos de ordem social que ocorrem durante a apresentação do projeto, e que são percebidos pelo cliente. 
Tabela 15 - Subcategoria 3.4.2 Apresentação

\section{Categoria: Características do processo projetual relevantes para a validação}

3.4 Subcategoria: Estágio(s) Projetual(ais) em que ocorre(m) a validação

3.4.2 Subcategoria: Apresentação

\begin{tabular}{|c|c|}
\hline Inf. / Linha & Transcrição da fala (unidades de análise) \\
\hline C, $128-132$ & $\begin{array}{l}\text { (...) Fica alguma falha, fica alguma falha... Aham! Porque um não tem muita... Eu acho que o } \\
\text { "designer X" sei lá, falta alguma... Pro "designer X", mesmo, falta alguma coisa na apresentação, } \\
\text { realmente ele se atrapalha na apresentação. E o "designer Y", ele não conhece a essência... faz } \\
\text { a parte comercial de vender a empresa. Não vender o projeto que ele criou, entendeu? (...). }\end{array}$ \\
\hline B, $194-197$ & $\begin{array}{l}\text { (...) Na verdade, eles faziam uma apresentação, um caderno de apresentação. Eles } \\
\text { apresentavam através desse caderno, e o mesmo material em uma imagem, em uma tela né, } \\
\text { passando, explicando o conceito do produto, a questão ergonômica, do desenho, do design, } \\
\text { tudo, as cores. (...). }\end{array}$ \\
\hline$E, 262-269$ & $\begin{array}{l}\text { (...) Uma coisa que é importante citar também e que tinha nessa apresentação da "designer X" e } \\
\text { do "designer Y" (...) mas o que foi bacana da "designer X"e do "designer Y" é que, nesse produto } \\
\text { em específico, eles apresentaram o estilo de vida de quem usa aquele produto. Então eles } \\
\text { inseriram esse produto dentro de um life-style que é o life-style do nosso cliente. Então isso nos } \\
\text { ajuda a enxergar possibilidades. (...). }\end{array}$ \\
\hline E, $285-287$ & $\begin{array}{l}\text { (...) Quando é um outdoor é muito mais fácil de você representar. Quando é indoor é muito mais } \\
\text { difícil e a "designer X" e o "designer Y" conseguiram traduzir isso nesse produto, tá? (...). }\end{array}$ \\
\hline$C, 87-90$ & $\begin{array}{l}\text { (...) Eles apresentaram uma apresentação em Power Point com imagens, com imagens em 3D } \\
\text { dos puxadores bem bacanas também, sempre linkando com essa questão do conceito, fizeram } \\
\text { também impressos... também, algumas imagens impressas dos modelos dos puxadores. Então } \\
\text { mais ou menos isso. (...). }\end{array}$ \\
\hline C, $117-119$ & $\begin{array}{l}\text { (...) Então... a apresentação só foi boa porque a pessoa que fez apresentou, no caso dos } \\
\text { puxadores, a pessoa que fez o projeto apresentou pra nós, que era o "designer X"Acho que é... } \\
\text { (...). }\end{array}$ \\
\hline$E, 246-256$ & $\begin{array}{l}\text { (...) É o que determinam a validação do projeto. (...). Então eu entendo que essa apresentação } \\
\text { da criação é um ponto crucial, sim. Porque é o ponto de convencimento que o profissional tem } \\
\text { para com o cliente dele, que é o mesmo que a gente tem no momento vai vender esse produto } \\
\text { para o nosso cliente depois. (...). }\end{array}$ \\
\hline
\end{tabular}

Fonte: Elaborado pela autora.

\section{Categoria: Fatores que influenciam a escolha do cliente sobre o} designer a ser contratado

A categoria Fatores que influenciam a escolha do cliente sobre o designer a ser contratado refere-se aos diferentes aspectos que motivam o cliente a contratar um designer em especial, ou seja: o que faz com que um designer seja contratado? Aqui, foram identificadas seis subcategorias: 4.1 Parceiros e concorrentes; 4.2 Proximidade geográfica do designer com a empresa; 4.3 Identificação/sintonia da empresa com o designer e seu portfólio; 4.4 Especificidade do projeto $X$ conhecimento do designer; 4.5 Amizade/proximidade de proprietários da empresa; e 4.6 Nome em ascensão ou reconhecido no mercado. 


\subsection{Parceiros e concorrentes}

A escolha do designer pelo cliente é influenciada pelos parceiros e/ou concorrentes da empresa, que já trabalharam ou apenas indicaram este profissional. O informante "B", por exemplo, relata ter contratado a designer, através da indicação de amigos, parceiros e fornecedores, como mostra a fala:

“(...) E daí nós chegamos ao nome da 'designer X', né, através de algumas indicações que nós tivemos (...). Então, devido a algumas indicações de alguns amigos, alguns parceiros, fornecedores e tal. (...)". $(B, 230-233)$.

Tabela 16 - Subcategoria 4.1 Parceiros e concorrentes

\begin{tabular}{l|l}
\hline \multicolumn{3}{c}{ 4. Categoria: Fatores que influenciam a escolha do cliente sobre o designer a ser } \\
contratado \\
4.1 Subcategoria: Parceiros e concorrentes
\end{tabular}

Fonte: Elaborado pela autora.

\subsection{Proximidade geográfica do designer com a empresa}

Neste caso, a escolha do profissional pelo cliente leva em conta a proximidade do escritório do designer com a sede da empresa, a fim de facilitar o processo, como ocorreu na situação citada pela informante "D":

“(...) Eu não sei se era a 'empresa $X$ ', tinha uma empresa da região que estava fazendo uns projetos com ela e a gente achou que seria bacana ter alguém daqui, para o processo ficar mais fácil. (...)". (D, 401-403). 
Tabela 17 - Subcategoria 4.2 Proximidade geográfica do designer com a empresa

4. Categoria: Fatores que influenciam a escolha do cliente sobre o designer a ser contratado

4.2 Subcategoria: Proximidade geográfica do designer com a empresa

\begin{tabular}{|c|l|}
\hline Inf. / Linha & \multicolumn{1}{|c}{ Transcrição da fala (unidades de análise) } \\
\hline D, 401 - 403 & $\begin{array}{l}\text { (...) Eu não sei se era a "empresa X", tinha uma empresa da região que estava fazendo uns } \\
\text { projetos com ela e a gente achou que seria bacana ter alguém daqui, para o processo ficar mais } \\
\text { fácil. (...). }\end{array}$ \\
\hline
\end{tabular}

Fonte: Elaborado pela autora.

\subsection{Identificação/sintonia da empresa com o designer e seu portfólio}

As falas de alguns informantes indicam que a escolha do designer é influenciada pela identificação/sintonia que ocorre entre a empresa e o profissional, ou seja, a empresa contrata um profissional cujo perfil ou portfólio apresentam similaridades com a identidade de sua própria marca e portfólio, por exemplo. Ao ser questionada sobre o perfil dos profissionais contratados pela empresa, a informante "A" explica:

"(...) que tem um posicionamento equivalente com o que a "empresa A" trabalha, que é uma marca mais sóbria, trabalha cores mais escuras, então pode olhar, no DNA dos estilistas que trabalhamos até então, nós não temos nenhuma marca que seja muito colorida, que seja muito popular, são todas marcas requintadas, mais sóbrias.(...)”. (A, 57-61).

Tabela 18 - Subcategoria 4.3 Identificação/sintonia da empresa com o designer e seu portfólio

4. Categoria: Fatores que influenciam a escolha do cliente sobre o designer a ser contratado

4.3 Subcategoria: Identificação/sintonia da empresa com o designer e seu portfólio

\begin{tabular}{|c|l}
\hline Inf. / Linha & \multicolumn{1}{c}{ Transcrição da fala (unidades de análise) } \\
\hline B, 148 - 151 & $\begin{array}{l}\text { (...) E hoje o "escritório X", assim, no mobiliário, ele é reconhecido mundialmente pelas outras } \\
\text { empresas que ele trabalha. Então hoje, por exemplo, na Itália, eles trabalham com a Poliform, } \\
\text { com a Porro, com a Varenna, com a Molteni, então são empresas que a gente tem como } \\
\text { inspiração... (...). }\end{array}$ \\
D, 152-157 & $\begin{array}{l}\text { (...) O "designer X" trabalhou com o gestor anterior que fazia essa parte de desenvolvimento } \\
\text { né... Então, ele tem cursos na Itália, e acho que o perfil dele casou com o perfil da empresa né, } \\
\text { que é importante também casar né, (...) E quando eu entrei na empresa nós também... tive uma } \\
\text { afinidade no nosso modo de trabalhar e aí ele permaneceu, então está aí há 10 anos né já... } \\
\text { (...). }\end{array}$ \\
A, 57 - 61 & $\begin{array}{l}\text { (...) que tem um posicionamento equivalente com o que a "empresa A" trabalha, que é uma } \\
\text { marca mais sóbria, trabalha cores mais escuras, então pode olhar, no DNA dos estilistas que } \\
\text { trabalhamos até então, nós não temos nenhuma marca que seja muito colorida, que seja muito } \\
\text { popular, são todas marcas requintadas, mais sóbrias. (...). }\end{array}$ \\
\hline
\end{tabular}

Fonte: Elaborado pela autora. 


\subsection{Especificidade do projeto $X$ conhecimento do designer}

As falas desta subcategoria revelam que a escolha do designer pelo cliente é influenciada pelo tipo de projeto a ser desenvolvido. Se a empresa precisa desenvolver um projeto na área de design de superfície, por exemplo, o designer a ser contratado deve ter conhecimento específico sobre esta área. A fala do informante "B" demonstra que a empresa buscou uma profissional especialista para desenvolver uma linha de produtos que exigia esse tipo de conhecimento, em especial:

“(...) Então, com isso, a gente falou então 'vamos atrás de uma pessoa que é especialista em design de superfície pra desenvolver essa linha pra nós, né' (...) Dizem que ela foi quem trouxe o design de superfície para o Brasil, né. (...)”. (B, $228-232)$.

Tabela 19 - Subcategoria 4.4 Especificidade do projeto $X$ conhecimento do designer

4. Categoria: Fatores que influenciam a escolha do cliente sobre o designer a ser contratado

4.4 Subcategoria: Especificidade do projeto $X$ conhecimento do designer

\begin{tabular}{|c|c|}
\hline Inf. / Linha & Transcrição da fala (unidades de análise) \\
\hline B, $228-232$ & $\begin{array}{l}\text { (...) Então, com isso, a gente falou então "vamos atrás de uma pessoa que é especialista em } \\
\text { design de superfície pra desenvolver essa linha pra nós, né" (...) Dizem que ela foi quem trouxe } \\
\text { o design de superfície para o Brasil, né. (...). }\end{array}$ \\
\hline D, $283-286$ & $\begin{array}{l}\text { (...) Isso, no nosso segmento ele já é conhecido e tem uma facilidade muito grande pra } \\
\text { desenhar estofados, porque o sofá, vamos colocar dessa forma, ele não é que nem uma mesa } \\
\text { que você desenha e ela é rígida... o sofá, além da roupagem, tem toda uma questão de } \\
\text { conceito... (...). }\end{array}$ \\
\hline$E, 121-123$ & $\begin{array}{l}\text { (...) A gente conduziu pelo "designer X" porque ele tem uma característica melhor para criação } \\
\text { desse tipo de produto. (...). }\end{array}$ \\
\hline C, $31-36$ & $\begin{array}{l}\text { (...) o escritório foi contratado para desenvolver uma linha de escritórios. Então, como, também, } \\
\text { nós não tínhamos expertise, nem conhecimento tão aprofundado. Porque, embora seja } \\
\text { mobiliário, tu precisa ter um conhecimento um pouco mais específico. Porque é um público } \\
\text { diferente, é uma maneira de comercializar diferente, enfim... Então nós achamos que seria } \\
\text { interessante contratar esse escritório para que trabalhasse realmente essa linha (...). }\end{array}$ \\
\hline
\end{tabular}

Fonte: Elaborado pela autora.

\subsection{Amizade/proximidade de proprietários da empresa}

Um determinado designer pode ser contratado devido à sua amizade ou proximidade com os proprietários da empresa, conforme justificou a informante "C" na seguinte fala: 
“(...) E também era uma empresa (escritório de design) conhecida dos donos da 'empresa C', então nós acabamos acreditando que eles fariam um projeto legal (...)". (C, 67-68).

Tabela 20 - Subcategoria 4.5 Amizade/proximidade de proprietários da empresa

4. Categoria: Fatores que influenciam a escolha do cliente sobre o designer a ser contratado

4.5 Subcategoria: Amizade/proximidade de proprietários da empresa

\begin{tabular}{|l|l|}
\hline Inf. / Linha & \multicolumn{1}{c}{ Transcrição da fala (unidades de análise) } \\
\hline C, 67 - 68 & $\begin{array}{l}\text { (...) E também era uma empresa conhecida dos donos da "empresa C", então nós acabamos } \\
\text { acreditando que eles fariam um projeto legal (...). }\end{array}$ \\
\hline
\end{tabular}

Fonte: Elaborado pela autora.

\subsection{Nome em ascensão ou reconhecido no mercado}

A Escolha do cliente sobre o designer a ser contratado é influenciada pelo nome/fama do designer no mercado. Neste caso, os informantes falam tanto sobre designers, cujo nome está em ascensão no mercado, como também sobre outros, cujos nomes já são reconhecidos e consolidados nesse meio. A informante "A" fala sobre o processo de escolha de estilistas (que aqui se entende como designers de moda) na empresa:

“(...) Então é feita uma seleção de estilistas que estão com nome forte no mercado, que vêm desempenhando um papel legal (...)". (A, 56-57).

Tabela 21 - Subcategoria 4.6 Nome em ascensão ou reconhecido no mercado

4. Categoria: Fatores que influenciam a escolha do cliente sobre o designer a ser contratado 4.6 Subcategoria: Nome em ascensão ou reconhecido no mercado

\begin{tabular}{|c|c|}
\hline Inf. / Linha & Transcrição da fala (unidades de análise) \\
\hline $\begin{array}{l}D, 280-281 \\
A, 56-57 \\
E, 379-387\end{array}$ & $\begin{array}{l}\text { (...) Não, o "designer X" já é mais assim, a questão de que ele já é conhecido no mercado né... } \\
\text { (...). } \\
\text { (...) Então é feita uma seleção de estilistas que estão com nome forte no mercado, que vêm } \\
\text { desempenhando um papel legal (...). } \\
\text { (...) o Studio, ele tem... ã... que na verdade antever algumas coisas que estão acontecendo. (...). } \\
\text { Mas a gente tem que se renovar no sentido de profissionais mais novos. Como é uma marca } \\
\text { que investe muito em design, nós temos, enfim, há mais de } 30 \text { anos a "empresa E" desenha } \\
\text { seus produtos. Então quem começou com isso foi a "designer X" e o "designer Y", nós estamos } \\
\text { sempre buscando profissionais que estão despontando, que estão aparecendo no mercado. E o } \\
\text { "designer Z" foi um desses profissionais. Hoje o "designer Z" tem uma expressão nacional e } \\
\text { internacional. (...). }\end{array}$ \\
\hline
\end{tabular}

Fonte: Elaborado pela autora. 
Como se pode perceber, as entrevistas realizadas possibilitaram a obtenção de uma série de achados sobre o processo de validação, que originaram as categorias listadas neste capítulo. As informações presentes em cada uma destas categorias são de grande importância para os objetivos da pesquisa, portanto serão discutidas, através dos tópicos no próximo capítulo. 


\section{DISCUSSÃO DOS RESULTADOS}

Neste capítulo, os resultados obtidos através da coleta de dados serão discutidos e comentados, com o intuito de responder aos objetivos da pesquisa. $A$ fundamentação teórica já apresentada nos primeiros capítulos auxilia no embasamento da discussão.

A análise dos dados coletados permitiu a identificação de cinco grandes tópicos de discussão, que serão explanados a seguir: 1) Presença de grupos heterogêneos para avaliação das proposições; 2) a validação ocorre ao longo do processo de desenvolvimento e em diferentes etapas; 3) a relação do cliente com o designer e os aspectos sociais da contratação; 4) a validação independe da linearidade do processo projetual; e 5) o processo de validação ocorre por meio da coalescência de seus componentes.

\subsection{PRESENÇA DE GRUPOS HETEROGÊNEOS PARA AVALIAÇÃO DAS PROPOSIÇÕES}

Em todas as entrevistas, os informantes mencionaram que profissionais de outros setores, além do design, costumam participar das avaliações e decisões sobre novos produtos. Na maioria dos casos, existe um comitê específico para a avaliação das novas proposições, onde, geralmente, participam: a direção de mercado ou marketing, o responsável pela engenharia e o responsável pela área comercial. Em alguns casos, são realizadas consultas com profissionais do departamento de compras/custos e também da produção.

Conforme demonstra o seguinte trecho, o responsável de cada setor contribui com a sua perspectiva relacionada à área em que atua:

“(...) Nós temos o comitê de produtos [...] Eu dou a opinião... 'Ah não... esse é legal esteticamente e vai ficar bonito', então eu participo com essa opinião. A pessoa da engenharia participa da questão... 'Ah não, funciona realmente, vai funcionar' O Marketing: 'Ah É legal trabalhar esse produto porque ele tá realmente "linkado" com o conceito da marca, onde ele vai estar posicionado no mercado' (...)”. (C, 175 - 183).

Uma das informantes, cuja marca de mobiliário possui uma rede de lojas, mencionou que existe também uma consulta aos lojistas, representados por outro 
comitê. A participante explica que os lojistas contribuem para a validação de uma proposição:

“(...) Então a gente tem um comitê formatado com representantes de algumas lojas e a gente consegue trocar esse tipo de informação no intuito de acertar cada vez mais um lançamento. (...)”. (E, 35 - 38).

A informante acredita que a validação também acontece no mercado, ou seja, se o produto tem aceitação pelos consumidores ou não -, sendo este um dos motivos pelos quais os lojistas são consultados.

A participação de diferentes atores, com suas respectivas visões e backgrounds, nas decisões sobre o projeto, reforça a ideia já exposta no capítulo 4, onde o projeto evolui através de uma negociação colaborativa, onde, conforme explica Mc Donnell (2009), cada participante contribui com informações do seu próprio território. Esse tipo de negociação também reafirma o pensamento de Cross (2011, p. 20, tradução nossa), que acredita que o design não é apenas um processo pessoal e cognitivo, mas "Um processo social de interação e negociação entre diferentes participantes onde cada um busca defender seu próprio mundo objeto."18

No método da pesquisa, sugeriu-se identificar apenas um sujeito, que seria responsável pelas avaliações e decisões das proposições de design. Na prática, entretanto, foram identificados vários sujeitos envolvidos nesse processo, sugerindo que as decisões são mais coletivas do que individuais. Mesmo assim, o departamento de design é quem costuma estruturar e conduzir esse processo, conforme exprime a fala da informante "A":

“(...) A equipe de Design estrutura todo o projeto, junto depois com a área de engenharia, que faz prototipagem do produto, afirma que aquela ideia tem consistência. A gente como Design leva isto para uma reunião de diretoria. (...)". (A, $23-27)$.

O envolvimento desses diversos profissionais - atuantes tanto interna quanto externamente à empresa -, nas decisões projetuais, reiteram o que foi mencionado no capítulo 4 (MEYER, 2010), sobre a existência da rede, onde diversos agentes participam e desempenham importância no processo. Para Meyer (2011), o designrede comporta um "Processo de design que somente efetiva-se pela solidez das mediações promovidas em sua rede". O autor (2011) explica também que, no

18 Do original em inglês: "a social process of interaction and negotiation between the participants who each bring to bear their own object world". 
design-rede, não se pode conceber o designer como um agente individual, responsável pela construção de um artefato e tampouco conceber o processo projetual como um processo realizado em equipe. Deve-se, sim, entender o designrede como um processo que se desenvolve nas tramas de uma rede, pois " $\mathrm{Um}$ artefato é tão bem sucedido, e tão estável, quanto maior for o número de aliados". (MEYER, 2011, p. 9).

Nas empresas analisadas, percebe-se que mesmo que as propostas sejam efetivamente desenvolvidas por designers externos, existe uma participação de vários outros atores, que contribuem com o seu próprio conhecimento e experiência, afetando muitas vezes os rumos do projeto, conforme mostra o seguinte trecho:

“(...) Então o comitê também avalia a criação. Vamos supor que a gente tivesse apresentado a Capadócia para o comitê e o comitê encontrou uma série de dificuldades e de problemas. A gente iria avaliar essas questões citadas, daqui a pouco ia reconfigurar o produto (...)". (E, $157-160)$.

Outro ponto que se pode defender aqui é a ideia da interdisciplinaridade presente no processo, onde conhecimentos de diferentes disciplinas são arranjados na busca de uma solução de design ideal. Nesse sentido, Friedman (2003) caracteriza a natureza do design como integrativa e interdisciplinar, no momento em que envolve - em diferentes aspectos e proporções -, os seguintes domínios gerais: ciências naturais, humanidades e artes humanitárias e liberais, ciências comportamentais e sociais, profissões humanas e serviços, artes aplicadas e criativas, tecnologia e engenharia.

Por integrar diferentes conteúdos, Meyer e Damazio (2010, p. 2), consideram o designer um bricoleur, que "Trabalha através de meios e mecanismos que não se utilizam de materiais pré-determinados que pertençam a um campo próprio." Segundo os autores, o designer, ao desempenhar uma tarefa, busca materiais diversos e fragmentos de outras áreas, que somente passam a fazer sentido ao projeto, quando combinados e alocados juntos. Da mesma forma, nas empresas pesquisadas, informações de diversas áreas e setores parecem "enriquecer" as novas propostas, com o intuito de qualificar o projeto do artefato e validá-lo também no próprio mercado, junto aos consumidores.

A discussão desse tópico possibilitou que se chegasse a algumas considerações importantes sobre o processo de validação: as decisões de design nas organizações costumam ter a participação de comitês, ou seja, grupos 
heterogêneos, formados por integrantes de diferentes áreas, tanto internas quanto externas à empresa (grupos de lojistas). Isto traz, para o processo projetual, perspectivas diversas e busca, fora do campo do design, outros materiais - o que qualifica o resultado do projeto e caracteriza a atividade como interdisciplinar. Por fim, entende-se que o designer não é o único responsável pela construção do artefato, já que o projeto se efetiva pelas mediações ocorridas em sua rede.

\subsection{A VALIDAÇÃO OCORRE AO LONGO DO PROCESSO DE DESENVOLVIMENTO E EM DIFERENTES ETAPAS}

Algumas considerações dos entrevistados levaram a crer que são diversos os momentos e estágios em que ocorre a validação de uma preposição. Em última análise, entendeu-se que o somatório desses momentos, desde o princípio, é o que efetiva a validação do projeto.

Ao questionar os entrevistados sobre a etapa projetual em que ocorria a aceitação de uma dada proposição de design, alguns mencionaram que a apresentação costuma ser um momento importante para o convencimento dos profissionais envolvidos, conforme mostra o seguinte trecho:

“(...) É o que determina a validação do projeto (a apresentação) (...). Então, eu entendo que essa apresentação da criação é um ponto crucial, sim. Porque é o ponto de convencimento que o profissional tem para com o cliente dele, que é o mesmo que a gente tem no momento vai vender esse produto para o nosso cliente depois. (...)". (E, 246 - 256).

Ao negociar com o designer, conforme a fala da informante denota, o cliente também age como um intermediário, um representante do cliente final ou usuário, defendendo seus interesses. Dessa forma, é durante a apresentação que o clienteempresa parece buscar as melhores soluções para o cliente final, avaliando diversas características da proposta.

A apresentação é o momento em que o designer expõe suas criações aos atores envolvidos, geralmente após um período de trabalho e de geração de ideias. Costuma ser o momento em que o designer traz ao cliente informações e representações, modelos bidimensionais ou tridimensionais, físicos ou virtuais, ou o que quer que ele julgue conveniente para expressar suas intenções projetuais. A apresentação também costuma ser o momento em que discursos e argumentos são 
utilizados, para justificar e apoiar ideias, além de convencer os atores envolvidos acerca da validade da proposta. Sendo assim, as apresentações geralmente são momentos de interação sobre o processo projetual, onde o designer busca, de forma mais consciente, validar as suas proposições e receber um feedback, pois nestas situações, geralmente, estão presentes os atores interessados na avaliação de tais ideias.

Além de ser um momento importante para essa argumentação acerca do projeto, é na apresentação que a criatividade do designer no desenvolvimento da proposição, bem como a qualidade na representação gráfica, são expostas ao cliente, como explica a informante "D" no trecho:

“(...) A questão do detalhe, a questão da costura né. Então quem tem mais tempo no segmento que nem o 'designer $X$ ', ele já traz com um desenho diferente né, quase que manual, o detalhe da costura né. É um outro perfil, então você acaba aprovando mais rápido... (...)” (D, 338 341).

Como demonstra a fala da informante, a habilidade do designer em representar graficamente determinada proposição influencia na percepção do cliente e, consequentemente, na sua validação. Uma proposição bem desenhada, com alta qualidade gráfica auxilia, de certa forma, no convencimento do cliente, no momento em que torna fácil a compreensão da mesma, bem como, demonstra uma habilidade do profissional e/ou sua equipe.

Relacionando a apresentação do projeto com os estágios projetuais descritos no capítulo 3, entende-se que a proposição apresentada nas reuniões com o cliente, refere-se à síntese da "resolução do problema" e que ao submetê-la à apreciação dos sujeitos envolvidos, também existe uma avaliação. A partir desta avaliação, é possível que, conforme descreve Dubberly (2004), a proposta necessite retornar para as fases de análise novamente, implementando observações mencionadas pelo cliente, num processo que pode ser cíclico.

Outras etapas projetuais que possuem importância no processo, segundo alguns informantes, são o briefing e a pesquisa. Conforme algumas falas, os clientes entendem que é fundamental que o designer saiba qual o desejo do cliente e qual o foco da proposta. Paralelo à isto, acreditam que uma pesquisa bem desenvolvida, somada ao conhecimento do designer, também serão cruciais para que o projeto possa ser validado: 
“(...) Acho que em primeiro lugar é o briefing, né? Tu ter realmente bem certinho o que tu deseja, o que tu quer fazer, ter esse foco de qual a proposta desse produto. E depois disso com certeza é a pesquisa, fazer uma boa pesquisa... o início! Se você conseguir fazer um início bem feito, tendo o conhecimento adequado, sabendo direitinho qual a proposta, acredito que tem muito mais chance. (...)". (C, 193 - 197).

Essas etapas - pesquisa e briefing - apresentam considerável importância tanto para o cliente quanto para o designer, pois servem de referência para as apresentações futuras do designer e, por isso, também influenciam na validação do projeto. Tais etapas integrariam a fase de análise, pois são momentos em que, segundo Koberg e Bagnall (1972, apud DUBBERLY, 2004), quebra-se o problema em partes para exame e que diversas informações são levantadas. Este é o estágio em que o problema e seu contexto são analisados, antes de convergirem para a geração ideias.

A compreensão adequada do briefing e do contexto da empresa parecem transmitir segurança ao cliente, pois, de certa forma, isto faz com que o designer apresente propostas mais coerentes com a realidade, bem como com os valores e objetivos dessa empresa. Segundo algumas falas da pesquisa de campo, os informantes acreditam que a compreensão do briefing, bem como o seu atendimento, resultam em um projeto mais acertado. Assim, mesmo que durante essa fase de análise não exista um momento específico de avaliação e julgamento por parte do cliente, ela se mostra crucial para a posterior validação das proposições.

Conforme mencionado no capítulo 3 , alguns problemas da prática profissional, são de natureza subdeterminada ou indeterminada, segundo Dorst (2003), apresentando lacunas e imprecisões. Isto, consequentemente, resulta em briefings mal resolvidos ou abertos o que pode afetar ou impedir uma validação de projeto posteriormente. Nesses casos, acredita-se que a postura do designer em relação aos problemas que se apresentam é um fator de grande importância. Ao realizar a exploração do espaço do problema, o designer pode repensá-lo estrategicamente, valendo-se do chamado contrabriefing (SCALETSKY; PARODE, 2008), que se trata de um reposicionamento do briefing. Através do contrabriefing, os problemas são questionados, no intuito de melhor compreendê-los, direcionando o projeto para o caminho mais adequado. 
Apesar da importância particular das etapas acima descritas - apresentação, pesquisa e briefing, destacadas pelos entrevistados, diversas evidências demonstraram que a validação tende a ocorrer ao longo de todo o processo de desenvolvimento do produto e em diferentes etapas e não é determinada em apenas um ou outro momento. Tais eventos podem ser tomados individualmente, mas apenas em conjunto são significativos para a validação. Alguns trechos demonstram, inclusive, que a aprovação de uma proposição depende do envolvimento do projeto com as diversas áreas. A seguinte unidade de análise exemplifica isso:

“(...) Eu te diria que não é um momento específico, tá? Mas... tem alguns pontos que eles são fundamentais, tá? É o envolvimento com todas as áreas, quando a gente fala da avaliação, até do comitê, enfim, existe um envolvimento com o processo. Então existe uma... uma determinada importância que se dá pra esse... pra esse envolvimento também. (...)". (E, 194 - 197).

A pluralidade de momentos importantes para a aprovação de uma proposição apenas reforça o que foi mencionado, que a validação ocorre ao longo de todo o processo, desde a contratação do profissional até a comercialização do produto no mercado. Isto porque, de nada valeria, por exemplo, que o designer convecesse o cliente sobre uma proposta durante a apresentação, se a produção deste artefato, no parque fabril, fosse avaliada como extramamente complexa ou de elevados custos.

As entrevistas demonstraram que o designer e suas proposições passam por constantes avaliações por parte do cliente. Isto pode ser justificado pelo fato de que um processo completo de desenvolvimento de produto pode durar um longo período de tempo e dessa forma, o profissional contratado estaria em contato com a empresa em diversos momentos. O designer, ao longo do período em que o produto é desenvolvido, tem diversas interfaces com a empresa, enfrenta diversos condicionantes, transita por diversos estágios projetuais, sempre com o intuito de validar a sua proposição e ver o artefato nascer.

A discussão desse tópico demonstrou que alguns estágios parecem ser relevantes para o processo de validação, como a apresentação - que é um momento de convencimento e interação com o cliente sobre a proposta; e a pesquisa e o briefing - que são momentos em que o campo de abrangência do projeto é explorado, para que, posteriormente, proposições coerentes e satisfatórias sejam apresentadas. Apesar disso, a pesquisa de campo indicou que diversos estágios 
podem ser relavantes ao mesmo tempo, ou com a mesma intensidade, para o cliente e para a validação das proposições. Estas, por sua vez, são avaliadas constantemente, de forma que vários requisitos sejam atendidos, ao longo de todo o período em que o projeto se desenvolve.

\subsection{A RELAÇÃO DO CLIENTE COM O DESIGNER E OS ASPECTOS SOCIAIS DA CONTRATAÇÃO}

Os dados encontrados na pesquisa de campo sugerem que aspectos da contratação do designer pelo cliente e a relação entre cliente e designer também são significativos para a validação das proposições e influenciam nas negociações a respeito do projeto, conforme demonstram as categorias da tabela de análise de conteúdo "Evidências de Validação relacionadas ao designer contratado" e "Fatores que influenciam a escolha do cliente sobre o designer a ser contratado".

Alguns dos fatores que influenciam a escolha do cliente sobre o designer parecem já ser um critério preliminar de validação, como se pode verificar em algumas subcategorias, como por exemplo "Identificação/sintonia da empresa com o designer a ser contratado". Ao analisar as unidades dessa subcategoria, entende-se que ao contratar um profissional com o qual o cliente se identifica, muitas vezes pelo seu portfólio, existe uma grande probabilidade do trabalho ser validado. A fala seguinte demonstra o interesse do cliente pelo portfólio do escritório:

“(...) E hoje o 'escritório $X$ ', assim, no mobiliário, ele é reconhecido mundialmente pelas outras empresas que ele trabalha. Então hoje, por exemplo, na Itália, eles trabalham com a Poliform, com a Porro, com a Varenna, com a Molteni, então são empresas que a gente tem como inspiração... (...)" (B, 148 - 151).

Quando existem identificações dessa ordem - antes mesmo que haja a contratação do profissional -, será muito provável que as proposições apresentadas estejam em sintonia com o perfil da marca ou com o que o cliente espera. Isto pode ocorrer porque nesses casos o cliente visualiza no designer e seus trabalhos desenvolvidos algumas características similares ao portfólio de sua própria empresa ou características que deseja e vislumbra para os próximos projetos a serem desenvolvidos. O portfólio do profissional fornece uma prévia do que ele pode 
apresentar ao cliente e no momento de análise deste portfólio já pode haver uma sintonia entre cliente e designer.

Situação similar ocorre quando o cliente recebe indicação ou é apresentado para um designer através de um parceiro de trabalho ou fornecedor. Ou ainda, quando o cliente conhece o designer através de um concorrente de seu segmento, por trabalhos já realizados para este. Nesses casos, também existe um conhecimento prévio sobre o perfil do designer, ou uma referência positiva, motivando a sua contratação. Isto indica, por exemplo, que se o designer já desenvolveu trabalhos bons para terceiros, provavelmente fará algo similar para 0 cliente que o contratou.

Os motivos para a contratação dos designers citados acima, relacionados a indicações de terceiros e à identificação da empresa com o designer contribuem positivamente para a validação, pois podem desencadear, ao longo das negociações sobre o projeto, uma relação de confiança e admiração, como mostra o seguinte trecho, do mesmo informante citado acima:

“(...) no momento que teve essa aproximação, a gente começou a pesquisar mais, e assim, e depois a gente começou a se interessar e admirar o trabalho deles (...)". (B, 146 - 148).

O informante B revela, no decorrer da entrevista, que as proposições apresentadas pelo escritório contratado eram aceitas na empresa com facilidade, motivadas pela admiração que haviam adquirido pelos designers. Tais motivos, muitas vezes, sobrepõem-se a fatores técnicos do projeto, o que implica dizer que os projetos podem nem ser tão bons, mas são validados, devido ao escritório que o fez. Nesse caso citado, a identificação da empresa com o designer influenciava a validação das proposições apresentadas pelo escritório.

Outro motivo que influencia a contração do designer pelo cliente, bem como a posterior validação da proposição, é o conhecimento que o profissional apresenta sobre determinado tipo de projeto, ou seja, busca-se um designer especialista em uma área cujo escopo do projeto necessita. Mesmo definindo apenas o segmento moveleiro para a realização da presente pesquisa, alguns informantes mencionaram projetos com necessidades específicas dentro desta área, como: design de superfícies, design de mobiliário coorporativo e design de estofados.

Alguns casos citados pelos entrevistados demonstraram que, quando não existe a especialidade ou conhecimento mais aprofundado do designer sobre 
determinada área, o processo torna-se mais difícil e lento, gerando insegurança por parte do cliente, como exprime a fala:

“(...) Exatamente! Né, então, o estofado pra ela, era relativamente novo. É claro, toda pessoa precisa da experiência pra chegar lá na frente né, é uma coisa natural, seja em qualquer área, né... Mas o processo fica diferente, então você acaba não ficando tão tranquila... (...) O processo fica demorado também. (...)" (D, 383 - 388).

Esse tipo de insegurança parece dificultar a validação de uma proposição, pois quando o próprio designer contratado não apresenta o conhecimento necessário para o projeto, passa a não dominar algumas questões relacionadas ao desenvolvimento do produto, e dessa forma, não transmite segurança ao próprio cliente.

Os informantes justificam que o designer, que possui o conhecimento específico sobre o tipo de projeto do qual a empresa necessita, apresenta mais domínio nas representações gráficas também, como, também, o conhecimento técnico necessário para a produção do artefato. A seguinte fala exemplifica isto:

“(...) É, então aquela questão que nem a gente comentou do 'designer $X$ ' né: 'Oh, aqui quem sabe a gente bota uma espuma assim, a gente coloca uma percinta tal, a gente coloca uma manta tal pra dar um fofo'. Então ele já tá falando a linguagem do pessoal técnico. (...)”. (D, 422 - 425).

Esse conhecimento do profissional sobre a área de projeto na qual atua parece propiciar confiança e segurança ao cliente e, por isso, repercute em uma avaliação positiva das proposições, favorecendo, por consequência, o processo de validação. Trata-se de um domínio do campo no qual o designer está transitando, uma experiência prévia sobre o mesmo, além de conhecimentos de diversos elementos daquele meio.

$\mathrm{Na}$ literatura, Cardoso (2013, p. 252) acredita que "O aprofundamento e o estudo atribuem ao trabalho uma densidade que o diferencia do comum". O autor (2013, p. 251) defende a ideia da erudição como "Fator determinante da atuação profissional do designer" e esclarece que o termo, neste contexto, não se refere a algo de caráter elitista ou excludente, mas a "Um amplo conhecimento geral e algum aprofundamento maior em áreas específicas", ambos motivados pela curiosidade intelectual genuína. (CARDOSO, 2013, p. 252). 
O autor explica que no Brasil, infelizmente, a pretensão da maioria das faculdades parece ser a da profissionalização rápida, produzindo "Trabalhadores qualificados rapidamente e em série", enquanto a verdadeira tarefa do ensino superior deveria ser a de formar uma classe de trabalhadores capaz de pensar com autonomia sobre o trabalho que exerce. Como isto dificilmente acontece no ensino superior, sugere-se que o aluno busque desenvolver essas habilidades e valores em outras instâncias, fora do ensino curricular. Segundo o autor, "Os melhores designers são os que sabem incutir aos seus projetos um nível de erudição maior do que seria exigido apenas para cumprir minimamente o briefing proposto". (CARDOSO, 2013, p. 251). Em outras palavras, o autor acredita que os melhores profissionais são aqueles que vão além do que foi exigido pelo cliente, não limitando-se a atuar apenas com o que foi fornecido ou solicitado.

Outro aspecto que parece favorecer a validação é o tempo de contrato entre o cliente e o designer, onde a experiência e conhecimento do profissional sobre a marca, produto e perfil de usuário, por exemplo, também alimentam um tipo de confiança no cliente, como exemplifica a seguinte fala:

“(...) Existe uma facilidade com os profissionais que têm mais tempo de casa. Então posso citar a 'designer $X$ ' e o 'designer $Y$ ' que estão há mais tempo que o 'designer $Z$ '. (...) isso tudo são experiências que o profissional vai adquirindo que vão resultar num trabalho mais acertado. (...). (E, $115-120)$.

Este relato demonstra que um tempo maior de experiência da empresa com o designer, ou seja, um contrato mais longo entre ambos, facilita as negociações sobre o projeto, já que nestes casos, o designer possui uma maior familiaridade com a empresa e a sua forma de atuar. Ao possuir essa bagagem prévia, o designer tende a apresentar proposições mais acertadas, transmitindo uma segurança maior ao cliente, e portanto, suas ideias serão mais facilmente aceitas.

\subsection{A VALIDAÇÃO INDEPENDE DA LINEARIDADE DO PROCESSO PROJETUAL}

Conforme descrito na revisão teórica, algumas metodologias de design descrevem o processo de design como uma sequência de atividades ou etapas. (PASCHOALIN, 2012). A pesquisa de campo demonstrou, entretanto, que esse tipo de metodologia linear não influencia na validação de uma proposição, ou seja, para 
que um projeto seja aprovado, o designer não necessita seguir etapas sequenciais, prescritas por métodos projetuais. Alguns informantes acreditam que a validação pode ocorrer de forma espontânea sem relação com o processo projetual, como afirma a informante:

“(...) Foi muito espontâneo, foi algo que não seguiu processo nenhum (...)". (E, 431).

Nesses casos em que o projeto é validado independente de etapas projetuais sequenciais, interrompendo o fluxo normalmente esperado, acredita-se que aspectos ligados ao próprio designer e sua capacidade se sobressaem em relação aos demais fatores. Durante uma das entrevistas, a informante relatou um caso em que o designer veio até a empresa para conhecê-la e, antes de firmar o contrato ou de ter recebido algum briefing, ele já apresentou o desenho de um artefato:

“(...) Não foi passado um briefing e ele veio com o produto. Ali foi, por isso que eu te disse que foi muito engraçado. Porque ele veio pra uma conversa, pra gente se conhecer, saber como é que era o processo de trabalho dele, enfim, né? (...) E ele apresentou o produto e eu disse... 'faz esse produto porque eu acho que...' e aconteceu, porque realmente a poltrona, enfim, estampou campanha institucional, tá nas mídias sociais, assim, é um sucesso. (...)”. (E, $422-429)$.

No caso acima, não se seguiu a ordem das atividades de um processo projetual tradicional, onde a síntese, ou seja, fase de criação da proposição ocorreria após a fase de análise - etapa em que os dados são levantados e o briefing é estudado. Aparentemente, o fato do projeto não ter seguido a ordem esperada das etapas não afetou a sua validação pelo cliente, dado o fato de que o resultado do trabalho, segundo a informante, foi um sucesso. Acredita-se que, aqui, fatores relacionados ao perfil do profissional estiveram em jogo, fazendo com que o produto tivesse sido aprovado desta forma.

Outra participante também menciona o quanto a proposta pode ser reavaliada pelo próprio designer, independente da linearidade do processo, como mostra a fala:

“(...) 'Briefa', cria e entrega, não é esse fluxo perfeito. Tanto que o projeto do 'designer $X$ ', ele começou com uma ideia, que nos vendeu também (...). Então ele nos vendeu uma ideia, a gente trabalhou sobre uma ideia por uns 2 ou 3 meses. E quando o projeto estava prestes a ser entregue, ele mudou a ideia, ele mudou totalmente a ideia. (...)". (A, 122 - 130). 
Neste caso, após a etapa de criação, o designer retornou à fase de avaliação e análise, para então gerar novas ideias e modificar o próprio projeto - o que provavelmente qualificaria a proposta e facilitaria a sua aprovação junto aos demais interessados.

Os exemplos citados tratam de processos projetuais que se aproximam à visão de Dorst (2003) - que acredita no design como um processo de refinamento da formulação de um problema, juntamente com as ideias para a solução -, e à visão de Schön (2000) - que acredita na conversação reflexiva durante o processo projetual, onde o próprio projeto fornece respostas para o designer. Essas abordagens, que costumam ser as mais amplamente utilizadas, não apresentam estágios projetuais com limites bem definidos, conforme os casos exemplificados, já que são constantes as análises, sínteses e avaliações por parte do designer e, no caso da pesquisa, também por parte do cliente.

\subsection{O PROCESSO DE VALIDAÇÃO OCORRE POR MEIO DA COALESCÊNCIA DE SEUS COMPONENTES}

A pesquisa de campo apontou diversas evidências através das quais os clientes validam proposições de design. Todas elas desempenham importância neste processo de negociação, em que participam o cliente e o designer. De acordo com o momento do processo projetual, diferentes aspectos podem ser avaliados. Por exemplo: os critérios de escolha de um determinado designer para o projeto podem ser tão importantes para a sua validação quanto a forma como as proposições são apresentada na empresa. As evidências alcançadas servem de apoio às decisões do cliente, quando este avalia o trabalho do designer, motivandoo a aceitar uma determinada proposição ou não.

Algumas evidências estão relacionadas ao processo projetual, como a qualidade do conceito e do design, em si, do artefato; outras são ligadas a questões estritamente técnicas, como a adequação da proposição à capacidade fabril da empresa; outras ainda são de ordem emocional, como a capacidade de provocar "encantamento" no cliente e, por fim, algumas são de ordem estratégica, como a capacidade da proposta de inovar e de se adequar às estratégias da empresa. 
A evidência que diz respeito à adequação da proposição às estratégias da empresa envolve aspectos que deveriam ser considerados pelo designer em praticamente todos os seus projetos. Tais aspectos referem-se à identidade do produto, da marca, e à própria estratégia da empresa, por exemplo, conforme o informante "B" salienta:

“(...) Na realidade, é que assim, que a gente vê como bem importante, é que a realidade daquilo que eles estão nos propondo, é que tenha muito a ver com a identidade da empresa, identidade do produto, identidade marca (...) Porque não adianta eles apresentarem o projeto sem conhecer a empresa a fundo ou aonde a gente pode chegar, porque não vai ter sintonia né. (...)" (B-416-422).

Pode-se entender que o cliente, conforme demonstra a fala, avalia a coerência do projeto com a realidade presente e futura da empresa. Ele avalia a proposta em relação a um contexto, e não apenas isoladamente. Por exemplo: uma empresa que tem como objetivo contribuir para a sustentabilidade do planeta nos próximos anos não estaria interessada em desenvolver produtos que atendam apenas a requisitos técnicos e estéticos. As proposições apresentadas precisam posicionar-se juntamente com os objetivos da empresa, precisam traduzir essas questões em suas caracetrísticas físicas e na própria forma de produção dos artefatos. Acredita-se que esta sintonia ou coerência pode estar relacionada a uma pesquisa bem feita junto à empresa e a um briefing claramente compreendido e assimilado pelo designer. Além do informante mencionado anteriormente, outros também destacaram a importância da adequação da proposição às estratégias da empresa, o que implica dizer que as organizações estão, cada vez mais, trazendo o design para o âmbito estratégico.

Nesse sentido, Zurlo (2010) afirma que ajudar a definir a identidade e explicitar o modelo organizacional é âmbito do design estratégico. O modelo, segundo o autor, corresponde à filosofia, à imagem organizacional, ajudando a indicar uma direção. $\mathrm{E}$ a identidade, por sua vez, é "a soma das identidades de seus fundadores e de seus membros, assim como de um sistema complexo de atores que se configuram como partes interessadas por aquilo que a organização é capaz de realizar." (ZURLO, 2010, p. 3). De forma geral, portanto, o design estratégico, ocupa-se de projetos que são desenvolvidos considerando esses aspectos - filososfia, imagem e identidade organizacional, os quais são considerados relavantes para a validação do projeto pelos informantes. 
Além das evidências citadas - ligadas à proposição de design -, que motivam o cliente a validar o projeto, apresentam-se ainda fatores ligados ao designer, que também contribuem para a validação, como a admiração e confiança que o cliente tem no profissional, a experiência e contrato firmado entre esses atores, além do conhecimento específico do designer sobre o tipo ou área de projeto, conforme já citados no tópico 7.4 .

Como foi visto na revisão bibliográfica, a literatura pouco explora a validação na área do design. Os estudos de design exploram o termo mais no sentido de verificação e avaliação de características físicas e propriedades técnicas de produtos. Os achados da pesquisa, entretanto, são suficientes para demonstrar que o processo de validação de novos projetos envolve muitos outros aspectos, que vão além disso, incluindo fatores de ordem social.

Dada a variedade de evidências sobre o processo de validação, alcançadas através da pesquisa de campo, chega-se ao que é chamado de coalescência - onde aspectos isolados formam um todo. Segundo o Dicionário Merriam-Webster (2015, tradução nossa), a palavra coalescência refere-se a "a) unir em um todo; b) unir para um fim comum"19, "surgir a partir da combinação de elementos distintos"20. Nesse sentido, constata-se que uma espécie de coalescência dos componentes observados nos resultados da pesquisa de campo oferecem um entendimento razoável sobre como ocorre a validação no design.

Salienta-se, também, que não se pode considerar um motivo de validação mais importante que outro. Isoladamente, essas evidências não significam muito para a validação. Em alguns momentos, o cliente se atém a alguns aspectos, em outros, ele se preocupa com outros, em proporções e medidas variadas. Os motivos para a contratação do designer $X$ ou $Y$ pelo cliente são importantes, mas também a relação que estes desenvolvem durante o projeto também o é. A qualidade do design do artefato e do conceito da proposta, a inovação e adequação às questões técnicas da empresa são relevantes para o cliente. Mas, também, a forma como o designer compreende o briefing e apresenta a proposta o são. O processo de validação de uma proposição, se tomado desde a contratação do profissional, compreende um somatório de evidências, que seria quase impossível privilegiar uma em detrimento de outra.

\footnotetext{
${ }^{19}$ Do original em inglês: "a) to unite into a whole; b) to unite for a common end".

${ }^{20}$ Do original em inglês: "to arise from the combination of distinct elements".
} 
Dessa forma, a presente pesquisa, procurou ampliar este processo, pouco abordado nos estudos de design, trazendo os aspectos de diferentes naturezas que se mostraram relevantes ao olhar do cliente no desenvolvimento de um projeto. 


\section{CONSIDERAÇÕES FINAIS}

Procurou-se, com a presente pesquisa, explorar o tema da validação na área do design, através da ótica do cliente, e, para tanto, alguns procedimentos foram realizados.

Primeiramente, foi feita uma investigação sobre o tema da validação. Esta medida foi importante para entender que o termo é utilizado em diferentes contextos e que o sentido pode se modificar bastante. No design, o assunto costuma ser tratado no sentido de verificação e avaliação de características físicas e desempenho dos artefatos. Krippendorff (2006), entretanto, explica que, como o projeto não é um futuro observável, como ocorre em outras áreas, o designer precisa argumentar e convencer os atores envolvidos sobre o potencial de suas ideias para, então, fazer com que estes validem suas proposições. O tema, portanto, foi explorado nesse sentido durante a pesquisa.

Posteriormente, abordou-se o processo projetual através de dois vieses diferentes: primeiro compreendendo os estágios metodológicos que normalmente compõe o projeto e, posteriormente, investigando as dinâmicas sociais que o envolvem. Tais dinâmicas se revelam na negociação entre o cliente e o designer para se chegar a um resultado projetual favorável para ambos, mas, em particular, ao cliente, que é aquele que investe seus recursos financeiros para que o artefato venha a existir. Por esse motivo, também foi abordada a questão da empatia, a qual o designer costuma incorporar ao lidar com necessidades e demandas alheias. Essas medidas foram relevantes, pois possibilitaram um conhecimento mais aprofundado sobre o universo do projeto, no que diz respeito às atividades do designer durante a projetação e também no que tange ao tipo de interação que ocorre entre ele e o cliente na discussão sobre um projeto.

Ao realizar a pesquisa de campo, as entrevistas trouxeram uma grande variedade de tipos de validação e uma série de considerações significativas sobre o tema na área do design. Tais evidências são apresentadas com mais clareza na seção de discussão dos resultados, mas serão brevemente comentadas, considerando os objetivos almejados na pesquisa:

1. Observou-se a formação de comitês heterogêneos nas organizações para avaliação das proposições, os quais são constituídos por participantes de diferentes áreas. Tais grupos contribuem consideravelmente para este processo, no 
momento em que agregam diferentes visões sobre um mesmo artefato. Esta interdisciplinaridade e multiplicidade de visões, presentes no processo de validação substitui a ideia da centralidade nas decisões organizacionais. Acredita-se que 0 somatório de opiniões e olhares resulta em proposições cada vez mais acertadas. Segundo Meyer (2011, p. 9), "Um artefato é tão bem sucedido, e tão estável, quanto maior for o número de aliados". Sendo assim, a perspectiva do cliente não se constitui na visão de um só indivíduo, mas, sim, no somatório de diferentes perspectivas, onde sujeitos com diversos backgrounds estão envolvidos.

2. A pesquisa demonstrou que não existe um momento ou estágio único do processo projetual em que ocorre a validação. Ao contrário, ficou evidente que ela se desdobra ao longo de todo o processo de desenvolvimento e em diferentes etapas, desde a contratação do profissional. A etapa da apresentação se mostrou crucial para a validação, por exemplo, pois é um momento de convencimento sobre as ideias, onde as dinâmicas sociais com o cliente ocorrem. Mas outros momentos também se mostraram relevantes para o processo - como a pesquisa e o briefing, já que estes influenciam na futura validação do projeto. Concluiu-se, portanto, que não é apenas a apresentação, o briefing ou a pesquisa que são determinantes para a validação, mas todo o curso do processo se mostrou importante, bem como o envolvimento do projeto com as diferentes áreas da empresa.

3. Aspectos da relação do cliente com o designer e da própria contratação do designer apresentaram grande influência sobre o processo de validação de uma proposição. A pesquisa demonstrou que a experiência de trabalho do designer com a empresa, bem como a confiança e admiração pelo profissional, por exemplo, facilitam as negociações sobre o projeto, influenciando positivamente a validação de uma proposição. Os motivos pelos quais os designers são contratados, que são de diferentes ordens, também são significativos para o processo. A indicação do profissional por um parceiro de trabalho ou fornecedor do cliente são casos que, geralmente, transmitem confiança e segurança para a empresa, como relataram alguns entrevistados. Da mesma forma, a contratação de um designer que é especialista ou reconhecido por atuar em determinado meio, também, faz com que o cliente se sinta mais seguro, facilitando a validação das proposições. Em alguns casos, aspectos da contratação podem até mesmo superar outros do processo projetual, como acontece com designers cujos nomes já são reconhecidos no mercado ou que têm portfólios atraentes. 
4. A validação de uma proposição demonstrou não ter relação com um processo projetual sequencial, linear, e com etapas bem definidas. Esta consideração vem ao encontro de pressupostos mais contemporâneos sobre a atividade de design, tais como: a evolução do problema de projeto juntamente com a sua solução, em constantes análises, sínteses e avaliações por parte do designer (DORST, 2003); e o processo projetual como uma atividade exploratória e reflexiva, onde o próprio projeto fornece algumas respostas que o designer busca. (SCHÖN, 2000). Nesse sentido, alguns relatos dos entrevistados sobre o processo dos designers, comprovam, na prática, que boas soluções de design não dependem de um processo projetual sequencial e que a ausência da linearidade no processo não influencia e nem impede a validação.

5. A coalescência, ou seja, a combinação dos diferentes componentes, alcançados na pesquisa, oferece um entendimento razoável sobre como ocorre a validação no design. Como a discussão dos resultados apresentou, evidências de diversas naturezas motivam o cliente a aceitar uma proposição, assim como aspectos da contratação do designer e da sua relação com o cliente, também o influenciam nessa aceitação. Sendo assim, não se pode privilegiar um motivo em detrimento do outro, pois, na validação de uma mesma proposição, o cliente pode considerar diversos aspectos juntos. Ou ainda, o cliente pode, em alguns momentos, validar um projeto por apresentar uma inovação, ou um conceito interessante, por exemplo, e, em outros momentos, aceitá-lo em função da adequação do projeto à sua estrutura fabril, facilitando o processo de produção dos artefatos.

A pesquisa demonstrou estar em consonância com os conceitos de design estratégico, no momento em que a pesquisadora se inseriu nas organizações para compreender o que estava em jogo na validação de projetos de design. Nesse sentido se revelou que a pluralidade de atores e fatores envolvidos nessas decisões posiciona o design como elemento estratégico e de grande importância em tais organizações. $O$ envolvimento de diferentes áreas e perspectivas nas decisões projetuais, conforme a pesquisa apresentou, se constitui em uma capacidade do design estratégico: a possibilidade de poder aceitar todos os pontos de vista, conseguindo passar de um ponto de vista a outro. (ZURLO, 2010).

Acredita-se que, como limitações da pesquisa, poderiam ter sido entrevistados também os designers, no intuito de compreender o que eles entendem que é mais relevante para o cliente sobre o processo de validação. Isto, porque as 
experiências anteriores dos designers, de projetos já rejeitados ou validados, podem resultar em uma leitura bastante interessante sobre o que o cliente se atém.

Mais entrevistas com o cliente, também seriam interessantes para a pesquisa e fortaleceriam o argumento. Contudo, mesmo que um grande número de entrevistas fosse tomado para a pesquisa, nem assim seria suficiente para acessar todos os aspectos e motivos possíveis que fazem um cliente validar um projeto. Trata-se de pessoas diferentes, com diferentes backgrounds e experiências -, o que torna cada processo muito particular. Além disso, qualquer modificação de contexto, de tempo ou tipo de projeto, provocaria, possivelmente, mudanças na perspectiva do cliente.

O que se alcançou com a pesquisa, portanto, foi uma aproximação dos motivos que fazem o cliente validar uma proposição de design. Explorar essa perspectiva, compreendendo os aspectos relevantes para o cliente durante as negociações sobre o projeto, trouxe contribuições teóricas e práticas para tema da validação em design. 


\section{REFERÊNCIAS}

ASSOCIAÇÃO DAS INDÚSTRIAS DE MÓVEIS DO ESTADO DO RIO GRANDE DO SUL (MOVERGS). Apresentação. Bento Gonçalves, [2014?]. Disponível em: <http://www.movergs.com.br/apresentacao>. Acesso em: 25 out. 2014.

BAUER, M. W.; GASKELL, G. Pesquisa qualitativa com texto, imagem e som. Tradução de Pedrinho A. Guareschi. Petrópolis: Vozes, 2002.

BAXTER, Mike, Projeto de produto: guia prático para o design de novos produtos. São Paulo: Blucher, 2011.

BÜRDEK, Bernhard E. Design: história teoria e prática do design de produtos. São Paulo: E. Blücher, 2010.

CARDOSO, Rafael. Design para um mundo complexo. São Paulo: Cosac Naify, 2013.

CROSS, N. How designers think. In: Design thinking: understanding how designers think and work. cap. 4. New York: BERG, 2011.

DEN OUDEN, Elke. Innovation design. Creating value for people, organizations and society. London: Springer-Verlag, 2012.

DESERTI, A. Intorno al progetto: concretizzare l'innovazione. In: CELASCHI, F.; DESERTI, A. Design e innovazione: strumenti e pratiche per la ricerca applicata. Roma: Carocci Editore, 2007.

DORST, K. The problem of design problems. In: Design Thinking Research Symposium. Sydney: Sydney University of Technology, 2003.

DUARTE, R. Entrevistas em pesquisa qualitativas. Educar, Curitiba, n. 24, p. 213225, Editora UFPR, 2004.

DUBBERLY, Hugh. How do you design? A compendium of models. San Francisco, 2004.

EXNER K, LINDOW, K., BUCHHOLZ, C.; STARK, R. Validation of product-service systems - a prototyping approach. In: HODA, E. (Ed.). Product Services Systems and Value Creation. CIRP Conference on Industrial Product-Service Systems. 6., p. 68-73, 2014. Windsor: Elsevier B. V., 2014.

FINDELI, A. Rethinking design education for the 21st century: theoretical, mehodological and ethical discussion. Design Issues: v. 17, n. 1, Winter, 2001. 
FRIEDMAN, K. Theory construction in design research: criteria: approaches, and methods. Design Studies, 24, 2003.

GIL, A. C. Métodos e técnicas de pesquisa social. 6. ed. São Paulo: Atlas, 2009.

GOLDSCHMIDT, Gabriela. Criteria for design evaluation: a process-oriented paradigm. In: KALAY, Y. E. (Ed.). Evaluating and predicting design performance. NY: John Wiley \& Sons, 1992, p. 67-79.

GREEN, Graham. Experimental validation of the $R^{3} \mid$ design evaluation methodology. J. Design Research, v. 9, n. 1, p. 1-15, 2011.

JORDAN, Judith. V. The meaning of mutuality. Work in Progress, n. 23. Wellesley, MA: Stone Center Working Paper Series, 1986.

KELLEY, Tom; KELLEY, David. Creative confidence: unleashing the creative potential within us all. New York: Crown Publishing Group, 2013.

KRIPPENDORFF, K. The semantic turn. A new foundation for design. Boca-Raton: Taylor \& Francis, 2006.

LAN, André; ARTEAU, Jean; SIRARD, Christian. Method for validating a multicomponent safety system. Safety Science, v. 42, p. 493-517, 2004.

LE DANTEC, Christopher. Situating design as social creation and cultural cognition. In: CoDesign. v. 6, n. 5, p. 207-224, 2010.

; YI-LUEN DO, Ellen. The mechanisms of value transfer in design meetings. In: Design Studies. v. 30, n. 2, p. 119-137, 2009.

LOVE, Terence. Philosophy of design: a metatheoretical structure for design theory. Design Studies, v. 21, n. 3, p. 293-313, 2000.

MAO, Ji-Ye et al. The state of user-centered design pratice. Communications of the ACM, v. 48, n. 3, p. 105-109, 2005.

MARTINS, G.; THEÓPHILO, C. Metodologia da investigação científica para Ciências Sociais Aplicadas. São Paulo: Atlas, 2007.

MATTELMÄKI, Tuuli; VAAJAKALLIO, Kirsikka; KOSKINEN, Ilpo. What happened to empathic design? Design Issues, v. 30, n. 1, p. 67-77, 2014.

MC DONNELL, Janet. Collaborative negotiation in design: a study of design conversations between architect and building users. CoDesign, v. 5, n. 1, p. 35-50, 2009. 
MERRIAM-WEBSTER'S COLLEGIATE. Dictionary online edition. Disponível em: $<$ http://www.merriam-webster.com/thesaurus/validate>. Acesso em: 08 ago. 2014a.

. Disponível em: <http://www.merriam-webster.com/thesaurus/validation>. Acesso em: 08 ago. 2014b.

. Disponível em: <http://www.merriam-webster.com/thesaurus/validated>. Acesso em: 08 ago. 2014c.

. Disponível em: <http://www.merriam-webster.com/dictionary/coalescence>. Acesso em: 20 jan. 2016.

MEYER, Guilherme Corrêa. Conflito, negociação e transformação: o designer e o processo de desenvolvimento de produto. 2010. Tese (Doutorado em Design) -Programa de Pós-Graduação em Design, Departamento de Artes e Design, Pontifícia Universidade Católica do Rio de Janeiro PUC-RIO, Rio de Janeiro, 2010.

.Design-rede: repensando os interesses do design. Estudos em Design, v.19, n.1, 1-19, 2011.

; DAMAZIO, Vera. O designer, um bricoleur lidando com seus conhecimentos. Arcos Design, v. 5, n. 2, p. 35-40, 2010.

MORAES, Roque. Análise de conteúdo. Revista Educação, Porto Alegre, v. 22, n. 37, p. 7-32, 1999.

PASCHOALIN, Daniel Morais. O horizonte da conversação: concepções do processo projetual arquitetônico. 2012. Dissertação (Mestrado em Arquitetura e Urbanismo) - Programa de Pós-Graduação do Instituto de Arquitetura e Urbanismo, Universidade de São Paulo (USP), São Paulo, 2012.

PEDERSEN, Kjartan; EMBLEMSVAG, Jan; BAILEY, Reid; ALLEN, Janet K.; MISTREE, Farrokh. Validating design methods \& research: the validation square. In: ASME Design Engineering Technical Conferences, Sept.10-14, 2000, Baltimore, Maryland. Baltimore, p. 1-12, 2000.

SANDERS, Elizabeth B.-N.; STAPPERS, Pieter Jan. Co-creation and the new landscapes of design. CoDesign, v. 4, n. 1, p. 5-18, March, 2008. Disponível em: <http://www.tandfonline.com/doi/abs/10.1080/15710880701875068\#.UhEZ3NJWySo>. Acesso em: 15 nov.2014.

SCALETSKY, Celso Carnos; PARODE, Fábio Pezzi. Imagem e pesquisa blue sky no design. In: Congresso SIGraDi. 12., 2008, Cuba. Anais eletrônicos... Disponível em: <http://www.design.org.br/artigos_cientificos/Imagem-pesquisa-Blue-sky-nodesign.pdf>. Acesso em: 10 set. 2015.

SCHÖN, D. A. Educando o profissional reflexivo. Porto Alegre: Artmed, 2000. 
The reflective practitioner: how professional think in action. New York, Basic Books, 1983.

SERVIÇO BRASILEIRO DE APOIO ÀS MICRO E PEQUENAS EMPRESAS (SEBRAE). Oportunidades para o setor moveleiro. 2014. Disponível em: <http://www.sebrae2014.com.br/Sebrae/Sebrae\%202014/Boletins/1BO_M\%C3\%B3v eis_Junho_Nichos\%20\%281\%29.pdf>. Acesso em: 25 out. 2014.

VERGANTI, Roberto. Design, meanings, and radical innovation: a metamodel and a research agenda. The Journal of Product Innovation Management, v. 25, p. 436456, 2008.

VISSER, Froukje S. et al. Contextmapping: experiences from practice. CoDesign, v. 1, n. 2, p. 119-149, 2005.

ZURLO, Francesco. Design strategico. In: XXI Secolo, v. IV, Gli spazi e le arti. Roma: Enciclopedia Treccani. 2010. 


\section{APÊNDICE A - GUIA PARA PESQUISA DE CAMPO}

\section{Guia para Entrevista em Profundidade}

Aplicação da técnica de coleta de dados qualitativos - tópicos para entrevista

\section{Objetivo Geral}

Compreender a perspectiva do cliente sobre o processo de validação em Design, no segmento moveleiro

\section{Objetivos Específicos}

1. Identificar as principais evidências aos quais os clientes se atêm na validação de uma proposição de design;

2. Relacionar os aspectos presentes no processo de validação aos estágios de projeto;

3. Avaliar de que forma a validação de uma proposição em design está relacionada com aspectos do perfil do profissional contratado (ex: experiência, reconhecimento no mercado, premiações recebidas, etc.).

\section{Condições Gerais}

As entrevistas fazem parte da pesquisa de campo sobre a perspectiva do cliente sobre o processo de validação e serão feitas pela própria pesquisadora. Haverá dois tipos de informantes: clientes e designers, portanto, para cada tipo de informante, um guia diferente será utilizado nas entrevistas, contendo os tópicos a serem abordados. Será feito o registro em áudio. As entrevistas ocorrerão, preferencialmente, no próprio edifício da organização/escritório dos entrevistados.

\section{Introdução}

Agradecimentos 
Apesar dos efeitos desta circunstância incomum, espera-se sua livre expressão: interessa-me saber da forma mais legítima possível a sua percepção. Você pode falar o quanto quiser. Se tiveres comentários adicionais, sinta-se livre para me interromper.

A entrevista deve levar em torno de uma hora é totalmente confidencial e de natureza acadêmica.

\section{TÓPICOS PARA ENTREVISTA}

\section{Informantes: Clientes}

\section{Perfil do Informante}

Apresente-se.

(1) Fale do seu papel na empresa e

(2) há quanto tempo trabalha aqui.

(3) Além de você, outras pessoas participam das decisões sobre novos projetos na empresa? Quem?

\section{Relação da validação em design com o perfil do profissional contratado}

(1) Cite alguns dos últimos projetos desenvolvidos por designers na empresa.

(2) Quem fez?

(3) Já conheciam estes profissionais?

(4) Por que estes profissionais foram contratados?

(5) Ficastes satisfeito com os resultados?

Relação da validação em design com os demais estágios projetuais.

(1) Pensando nesses últimos projetos aqui desenvolvidos, houve algum momento em que você se sentiu mais convencido, persuadido acerca da proposta apresentada? Comente. 
(2) Qual etapa, ou quais etapas, projetuais considerastes mais importante(s) para a aprovação/aceitação dos projetos mencionados?

(3) Faça uma avaliação crítica desse momento. (Caso necessário, explicar brevemente as principais etapas projetuais).

\section{Evidências a que os clientes se atêm no processo de validação em design.}

(1) Você se lembra de algo nos projetos mencionados, que tenha sido crucial para a sua aprovação ou rejeição? Algo específico? Algo do designer? Em que momento isto ocorreu?

(2) Como costumam ocorrer os outros projetos de contexto de design na empresa? Comente sobre casos de sucesso e fracasso.

(3) Que materiais o designer usava nas reuniões?

(4) Você acredita que houve algum recurso utilizado pelo designer que o influenciou a aprovar a proposta?

(5) Existe algum procedimento-padrão utilizado para avaliação dos projetos de design na empresa?

\section{Finalizando}

Gostaria de falar mais algum ponto pendente? Há mais alguma colocação a ser feita?

Gostaria de agradecê-lo pela atenção e por dispor tempo a esta entrevista. Obrigada. 